\title{
Effect of Aspergillus and Bacillus Concentration on Cotton Growth Promotion
}

\section{Paola Andrea Escobar Diaz*, Roberta Mendes dos Santos, Noemi Carla Baron, Oniel Jeremias Aguirre Gil and Everlon Cid Rigobelo*}

Laboratory of Soil Microbiology, Faculty of Agricultural and Veterinary Sciences, Department of Agricultural Production Sciences, São Paulo State University, São Paulo, Brazil

There are no studies in literature on the effect of inoculant concentrations on plant growth promotion. Therefore, in the present study, two experiments were carried out, one under pot conditions and the other in the field with cotton crop, in order to verify the effect of Aspergillus and Bacillus concentrations on the biometric and nutritional parameters of plant and soil, in addition to yield. The pot experiment evaluated the effect of different concentrations, ranging from $1 \times 10^{4}$ to $1 \times 10^{10}$ colony-forming units per milliliter (CFU mL ${ }^{-1}$ ) of microorganisms Bacillus velezensis (Bv188), Bacillus subtilis (Bs248), B. subtilis (Bs290), Aspergillus brasiliensis (F111), Aspergillus sydowii (F112), and Aspergillus sp. versicolor section (F113) on parameters plant growth promotion and physicochemical and microbiological of characteristics soil. Results indicated that the different parameters analyzed are influenced by the isolate and microbial concentrations in a different way and allowed the selection of four microorganisms (Bs248, Bv188, F112, and F113) and two concentrations ( $1 \times 10^{4}$ and $\left.1 \times 10^{10} \mathrm{CFU} \mathrm{mL}{ }^{-1}\right)$, which were evaluated in the field to determine their effect on yield. The results show that, regardless of isolate, inoculant concentrations promoted the same fiber and seed cotton yield. These results suggest that lower inoculant concentrations may be able to increase cotton yield, eliminating the need to use concentrated inoculants with high production cost.

Keywords: rhizobacteria, Aspergillus sydowii, Bacillus sp., yield, growth promoters, inoculants

\section{INTRODUCTION}

The use of plant-growth promoting microorganisms (PGPMs) has increased in the world as an alternative to the excessive application of mineral fertilizers that can contribute to soil degradation, emission of polluting gases into the atmosphere, and reduction of biodiversity in different ecosystems (Singh et al., 2016).

Inoculants are products that have in their composition live microorganisms capable of promoting plant development with different mechanisms or modes of action, such as production of phytohormones and siderophores, phosphate solubilization, and induction of resistance against abiotic and biotic stresses (Bhattacharyya and Jha, 2012; Malusá and Vassilev, 2014). PGPM application has been carried out in several agricultural cultures, and many studies have been developed to elucidate its mode of action in plants to meet the new requirements of industries in the sector and agricultural producers. The microorganisms most frequently used as inoculants are fungi of the genera Trichoderma, Purpureocillium, Metarhizium, Beauveria, and Aspergillus 
(Behie and Bidochka, 2014; Samson et al., 2014; Alori and Babalola, 2018; Baron et al., 2018, 2020; Ahmad et al., 2020), and bacteria of the genera Azospirillum, Azotobacter, Bacillus, Enterobacter, and Streptomyces (Kloepper et al., 1989; Okon and Labandera-Gonzalez, 1994; Glick et al., 1999; Tahmatsidou et al., 2006; Marulanda et al., 2009; Pedraza et al., 2010; Diaz et al., 2019).

Under field conditions, PGPMs are applied in the form of formulated products, which contain inerts and additives in addition to the active ingredient, which is the microorganism. The search for new inoculant formulations, which enhance plant development in order to reduce the use of mineral fertilizers, thus contributing to more sustainable agriculture, is increasing (Malusá and Vassilev, 2014; Bizos et al., 2020). These new formulations have included increasing the concentration of microorganisms to be applied in the field. However, despite the advance in the use of inoculants in agriculture, there are few studies that have evaluated the effect of inoculant concentration on plant growth promotion, particularly in cotton. Thus, this theme has become essential to define whether the increase in the concentration of microorganisms is an important aspect related to product efficiency or whether it is just an aspect of commercial advantage.

In this study, cotton was used because it is a crop that stands out for its high demand for mineral fertilizers and phytosanitary products to ensure good productivity, a situation that causes serious changes in the environment (Michereff and Barros, 2001; Carvalho and Barcellos, 2012).

The aim was to determine the effect of different concentrations of microorganisms Bacillus velezensis, Bacillus subtilis, Aspergillus brasiliensis, Aspergillus sydowii, and Aspergillus sp. (versicolor section) on the growth of cotton plants under pot conditions in greenhouse and field conditions.

\section{MATERIALS AND METHODS}

\section{Study Location}

According to the Köppen and Geiger classification, the climate of the region corresponds to a tropical climate with dry season in the winter (Peel et al., 2007). The predominant soil at the site is classified as Red Eutrophic Latosol (Oxisol) with clayey texture (52\% clay, 23\% silt, and 24\% total sand) (EMBRAPA, 2006).

\section{Experiment 1: Determination of the Effect of Inoculation of Microorganisms at Different Concentrations in Greenhouse}

\section{Microorganisms and Inoculant Preparation}

Microorganisms (bacteria and fungi) used in this study belong to the collection of the Laboratory of Soil Microbiology, UNESP, Campus of Jaboticabal (Table 1) and were selected for presenting growth-promoting characteristics such as phosphorus solubilization, biological nitrogen fixation, and indole acetic acid production (Baron et al., 2018; Diaz et al., 2019; Milani et al., 2019).
TABLE 1 | Description of microorganisms.

\begin{tabular}{lcc}
\hline Microorganisms & $\begin{array}{c}\text { Code in the } \\
\text { collection }\end{array}$ & $\begin{array}{c}\text { GenBank deposit } \\
\text { number }\end{array}$ \\
\hline Bacillus subtilis & $\mathrm{Bs} 248$ & $\mathrm{MZ133755}$ \\
B. subtilis & $\mathrm{Bs} 290$ & $\mathrm{MZ133476}$ \\
Bacillus velezensis & $\mathrm{B}$ 188 & $\mathrm{MZ133757}$ \\
Aspergillus brasiliensis & $\mathrm{F} 111$ & $\mathrm{MZ133758}$ \\
Aspergillus sydowii & $\mathrm{F} 112$ & $\mathrm{MZ133759}$ \\
Aspergillus sp. (versicolor section) & $\mathrm{F} 113$ & $\mathrm{MZ133456}$ \\
Control & - & -
\end{tabular}

The microorganisms used in the study were pre-inoculated in Petri dishes containing nutrient agar for bacteria and potato dextrose agar for fungi. Incubation was carried out in BOD oven at $30^{\circ} \mathrm{C}$ for $24 \mathrm{~h}$ for bacteria and at $25^{\circ} \mathrm{C}$ for 7 days for fungi.

Each bacterial isolate was multiplied in Erlenmeyer flask containing $90 \mathrm{ml}$ of sterile nutrient broth medium inoculated with isolates prepared on Petri dishes. Flasks were incubated at $30^{\circ} \mathrm{C}$ for $24 \mathrm{~h}$ under agitation at $150 \mathrm{rpm}$. Then, absorbance readings of each isolate were carried out in spectrophotometer at $600 \mathrm{~nm}$ to determine the optical density. In addition, $100 \mu \mathrm{l}$ of each flask with the different isolates was seeded in Petri dishes containing nutrient agar for the determination and adjustment of cell concentrations (Kloepper et al., 1989).

For fungi, conidium suspension was prepared by scraping Petri dishes containing mycelium cultivated on potato dextrose agar for $7-10$ days at $25^{\circ} \mathrm{C}$. For scraping, $0.1 \%$ Tween 80 solution was used. Fungi suspensions obtained were filtered in sterile voile to remove excess mycelium. The determination of the conidium concentration of each fungus was performed by counting in Neubauer chamber. For all microorganisms (bacteria and fungi), concentrations of $1 \times 10^{4}, 1 \times 10^{6}, 1 \times 10^{8}$, and $1 \times 10^{10}$ colonyforming units/ml (CFU $\mathrm{mL}^{-1}$ ) were standardized for bacteria and conidia $\mathrm{ml}$ for fungi.

\section{Seed Inoculation}

Cotton seeds were individually inoculated with microorganisms (bacteria or fungi) by immersion for $8 \mathrm{~h}$ at $25^{\circ} \mathrm{C}$ (Jaber and Enkerli, 2016). Immersion was carried out in the dark under agitation at $130 \mathrm{rpm}$. This procedure was performed for all microorganisms and concentrations. After the immersion period, cotton seeds were sown in pots containing previously sieved soil.

Cotton seedlings were inoculated three times from the beginning to the end of the experiment at 15-day intervals. In each inoculation, $10 \mathrm{ml}$ of suspension containing the respective microorganism at concentrations of $1 \times 10^{4}, 1 \times 10^{6}, 1 \times 10^{8}$, and $1 \times 10^{10} \mathrm{CFU} \mathrm{mL} \mathrm{m}^{-1}$ for bacteria and conidia $\mathrm{ml}$ for fungi was applied per pot. Inoculations were performed by applying the inoculum at the base and stem of plants using graduated micropipette (Kasvi monocanal premium black k1-1000 PB).

\section{Experimental Design and Experiment Management}

The experiment was carried out at the Horticulture Sector of the "Júlio de Mesquita Filho" São Paulo State University (UNESP), 
Campus of Jaboticabal, São Paulo, Brazil. The experiment was arranged in a randomized block design with $6 \times 4$ factorial arrangement +1 additional treatment (control) with five replicates, totaling 125 pots. Microorganism factor sublevels were Bs248, Bs290, Bv188, F111, F112, and F113 (Table 1). Concentration factor sublevels were $1 \times 10^{4}, 1 \times 10^{6}, 1 \times 10^{8}$, and $1 \times 10^{10} \mathrm{CFU}$ or conidia $\mathrm{ml}^{-1}$. Pots of 5 -L capacity were filled with sieved soil (particles smaller than $1 \mathrm{~cm}$ in diameter) and fertilized according to previously performed soil analysis (Table 2) and nutritional recommendations for pot experiments proposed by Malavolta et al. (1997) for cotton crop. Nitrogen (N: 3.33 g urea/pot), phosphorus ( $\mathrm{P}: 5.5 \mathrm{~g} \mathrm{P}_{2} \mathrm{O}_{5} /$ pot), potassium (K: $1.66 \mathrm{~g} \mathrm{KCl} /$ pot), calcium (Ca: $6.25 \mathrm{~g}$ super single/pot), magnesium (Mg: $0.5 \mathrm{~g} \mathrm{MgO/pot),} \mathrm{sulfur} \mathrm{(S:} 3.125 \mathrm{~g}$ super single/pot), zinc ( $\mathrm{Zn:} 0.125 \mathrm{~g} \mathrm{ZnSO}_{4} /$ pot), boron (B: $0.025 \mathrm{~g} \mathrm{H}_{3} \mathrm{BO}_{3} / \mathrm{pot}$ ), molybdenum (Mo: $0.002 \mathrm{~g}$ molybdate/pot), copper ( $\mathrm{Cu}: 0.03 \mathrm{~g}$ $\mathrm{CuSO}_{4} /$ pot), and manganese ( $\mathrm{Mn}: 0.08 \mathrm{~g} \mathrm{MnSO}_{4} /$ pot) were added. All nutrients were mixed with the sieved soil 1 week before sowing. The moisture content of pots was kept around $70 \%$ of the field capacity with daily irrigations.

Five cotton seeds (Gossypium hirsutum-IMA7501 WS) were sown per pot; and 15 days after seedling emergence, thinning was performed, keeping one plant per pot. The experiment was carried out until the flowering of cotton plants, 70 days after emergence.

\section{Evaluated Parameters \\ Shoot and Root Dry Matter}

Plants were collected and separated into shoots and roots, washed in running water, and placed in paper bags for drying in oven with air circulation at $65^{\circ} \mathrm{C}$ until reaching constant weight. Root and shoot dry matter weight was determined using analytical scale.

\section{Preparation of Soil Samples}

Samples were separated into two subsamples of approximately $100 \mathrm{~g}$ each. A subsample was sieved and dried at room temperature for chemical analysis, and the other was kept in a refrigerator for microbiological analysis.

\section{Counting Bacteria Present in the Soil}

Ten grams of soil was placed in an Erlenmeyer flask containing $95 \mathrm{ml}$ of $0.1 \%$ sodium pyrophosphate saline solution. All Erlenmeyer flasks were shaken for $1 \mathrm{~h}$ at $130 \mathrm{rpm}$, and the contents of flasks were used to prepare serial dilutions following methodology proposed by Wollum (1982). Aliquots of $100 \mu \mathrm{l}$ of obtained dilutions were inoculated into Petri dishes containing nutrient agar medium or potato dextrose agar in triplicate. Plates were kept in $\mathrm{BOD}$ oven at $30^{\circ} \mathrm{C}$ for bacteria and $25^{\circ} \mathrm{C}$ for fungi.
The number of CFU $\mathrm{mL}^{-1}$ was verified after 24,48 , and $72 \mathrm{~h}$ (Vieira and Nahas, 2000).

\section{Counting of Endophytic Bacteria and Fungi}

Plants were separated into leaves and roots and washed with running water. Samples containing $3 \mathrm{~g}$ of each vegetative tissue (leaves and roots) were submitted to superficial disinfection to eliminate epiphytic microorganisms. Each tissue (leaf or root) was sequentially immersed in $70 \%$ ethanol for $1 \mathrm{~min}$, sodium hypochlorite solution $(2.0-2.5 \%$ active $\mathrm{Cl}$ ) for $4 \mathrm{~min}$, and $70 \%$ ethanol for $30 \mathrm{~s}$. Subsequently, tissues were washed three times with distilled water. Once washed and disinfected, tissues were macerated with $3 \mathrm{ml}$ of sterile $0.85 \%$ saline solution with the aid of a flask and a pestle (de Araújo et al., 2002). The macerated material was used to prepare serial dilutions, and $100 \mu \mathrm{l}$ of aliquots was seeded in Petri dishes containing tryptone soy agar (TSA) medium for bacterial isolation and potato dextrose agar for fungal isolation. Plates were grown in microbiological greenhouses at constant temperature of $30^{\circ} \mathrm{C}$ for $24 \mathrm{~h}$ for bacterial growth and at $25^{\circ} \mathrm{C}$ for 7 days in the case of fungal isolation (Caruso et al., 2000). Microorganism counts were performed in separate groups, fungi, and bacteria with their respective controls.

\section{Determination of the Phosphorus Concentration in Plants and Soil}

The determination of soluble soil phosphorus was carried out using the method proposed by Watanabe and Olsen (1965). For the determination of phosphorus in plants, phosphorus concentrations in roots and shoots were determined according to methodology proposed by Haag et al. (1975) and modified by Bezerra Neto and Barreto (2011).

\section{Determination of the Total Nitrogen Concentration in Plants and Soil}

The determination of the nitrogen concentration in shoots and roots was performed according to Haag et al. (1975) with sulfuric digestion of plant material to estimate the nitrogen concentration or dose associated with obtaining $90 \%$ of dry matter production. For the determination of total nitrogen in soil, the methodology proposed by Bremner and Mulvaney (1983) and modified by Wilke (2005) was used.

\section{Microbial Respiratory Activity}

The respiratory activity was determined by the method of quantification of released $\mathrm{CO}_{2}$ according to Jenkinson and Powlson (1976), using wide-mouth flasks with $100 \mathrm{~g}$ of soil (dry or wet). Inside flasks, two beakers (one containing $20 \mathrm{ml}$ of $\mathrm{NaOH}$, and the other $20 \mathrm{ml}$ distilled water) were placed, were

TABLE 2 | Analysis of soil used in greenhouse and field experiments.

\begin{tabular}{|c|c|c|c|c|c|c|c|c|c|}
\hline $\mathrm{pH}$ & OM & $\mathbf{P}$ & $\mathbf{K}$ & $\mathrm{Ca}$ & $\mathbf{M g}$ & $\mathbf{H}+\mathbf{A l}$ & S.B. & CEC & $\mathbf{V}$ \\
\hline $\mathrm{CaCl}_{2}$ & $\mathrm{~g} / \mathrm{dm}^{3}$ & $\mathrm{Mg} / \mathrm{dm}^{3}$ & & & $\ldots$ & $\ldots \ldots$ & $/ \mathrm{dm}^{3}$. & & $\%$ \\
\hline 6.9 & 10 & 23 & 0.7 & 79 & 13 & 11 & 93.4 & 104.2 & 90 \\
\hline
\end{tabular}

OM, organic matter; S.B., $\mathrm{Ca}+\mathrm{Mg}+\mathrm{Na}+\mathrm{K} ; \mathrm{CEC}, \mathrm{S} . \mathrm{B} .+\mathrm{H}+\mathrm{Al}$; V\%, (S.B./CEC) * 100. 
then sealed with plastic film, and incubated in the dark for 7 days. Microbial respiration was estimated from the amount of $\mathrm{CO}_{2}$ released from soil samples in a continuous air flow system free from $\mathrm{CO}_{2}$ and moisture. After incubation, the remaining $\mathrm{NaOH}$ was quantified by titration with $\mathrm{HCl}$.

\section{Microbial Biomass Carbon}

Microbial biomass carbon was determined by the irradiationextraction method (Islam and Weil, 1998; Mendonça and Matos, 2017), using microwave oven. After irradiation, samples were submitted to $0.5 \mathrm{~mol} / \mathrm{L}$ of potassium sulfate extractor, and microbial biomass carbon was determined by oxidation with $0.066 \mathrm{~mol} / \mathrm{L}$ of potassium dichromate followed by titration with $0.033 \mathrm{~mol} / \mathrm{L}$ of ammonia ferrous sulfate (Brookes et al., 1982).

\section{Statistical Analysis}

Prior to analysis of variance, data normality (the KolmogorovSmirnov test) and homogeneity of variances (Levene's test) were tested for each parameter evaluated. Data were transformed into $(\mathrm{x}+0.5)^{1 / 2}$ to comply with assumptions of the analysis of variance. Comparisons of means were performed using Tukey's test $(\alpha \leq 0.05)$. Analyses were performed using the R 3.4.1 open software for Windows (R Core Team, 2020).

\section{Experiment 2: Determination of the Effect of Inoculation of Microorganisms on Cotton Plants Under Field Conditions \\ Cotton Planting}

The experiment was carried out at the Teaching, Research and Extension Farm (FEPE) - UNESP, Jaboticabal, São Paulo, during the off season (January-June 2020). The field soil was classified as Red Eutrophic Latosol (Oxisol) with clayey texture. Soil chemical analysis is detailed in Table 2.

Soil fertilization was performed once before sowing using the 8-28-16 of NPK $+0.5 \% \mathrm{Zn}$ formula, with the amount of nitrogen $80 \%$ lower than the requirement to avoid masking the effect produced by microorganisms and their concentrations on cotton yield. Cotton was sown at spacing of $1 \mathrm{~m}$ between rows and 8-10 seeds per linear meter. The dimensions of the plot were $5 \mathrm{~m}$ in length by $5 \mathrm{~m}$ in width with useful area of $15 \mathrm{~m}^{2}$.

The microorganisms used in the experiment were selected based on results of experiment 1. Microorganisms Bs248, Bv188, F112, and F113 were tested at concentrations of $1 \times 10^{4}$ and $1 \times 10^{10} \mathrm{CFU}$ or conidia $\mathrm{ml}^{-1}$. The multiplication of these microorganisms was performed as previously described in experiment 1. Application was performed three times, every 15 days, using back sprayer with constant pressure. In this experiment, seeds were not inoculated, and the first application was carried out 7 days after the emergence of cotton seedlings.

Microorganisms were applied at dose of $1 \mathrm{~L}$ of suspension per hectare (ha). The amount of water used was $200 \mathrm{~L} / \mathrm{ha}(500 \mathrm{ml}$ per useful area of $15 \mathrm{~m}^{2}$ ). The control treatment was sprayed with water only. Cotton was manually harvested 151 days after seedling emergence. Seed cotton was harvested from plants of the useful plot $\left(15 \mathrm{~m}^{2}\right)$.

\section{Experimental Design and Experiment Management}

A randomized block design with $4 \times 2$ factorial arrangement +1 additional treatment (control) with four replicates was used. Microorganism factor sublevels were Bs248, Bv188, F112, and F113. Concentration factor sublevels were $1 \times 10^{10}$ and

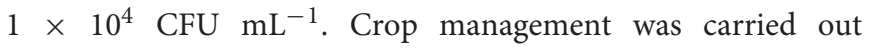
considering commercial management for the region.

\section{Evaluated Parameters}

Parameters were evaluated by manual harvesting of plants in useful plots. The weight of seed cotton was measured using analytical scale. After drying in oven with air circulation at $65^{\circ} \mathrm{C}$, seeds were manually separated from fibers and weighed on analytical scale. Fiber weight was obtained by the difference between the weight of the cotton harvested and the weight of the seed. Seed weight and fiber weight were estimated in $\mathrm{kg} / \mathrm{ha}$.

\section{Data Analysis}

Analyses were performed using the $\mathrm{R}$ software for Windows ( $\mathrm{R}$ Core Team, 2020). The normality and homogeneity of variances were assessed using the Shapiro-Wilk test and Levene's test ( $\alpha \leq 0.05)$, respectively. Treatments were analyzed using ANOVA, followed by Tukey's test $(\alpha \leq 0.05)$ to compare the mean of treatments.

\section{RESULTS AND DISCUSSION}

\section{Experiment 1: Determination of the Effect of Inoculation of Microorganisms at Different Concentrations in Greenhouse}

The results indicate that there was no interaction between microorganism factor and inoculant concentration for variables shoot, root, and total dry matter in cotton plants. This means that regardless of microorganism, the behavior was the same, given the different inoculant concentrations. Furthermore, there was no effect of the concentration factor on variables shoot, root and total dry matter, nitrogen content in root dry matter, phosphorus in shoot dry matter, and biomass carbon; however, there was a significant effect of the microorganism factor on variables shoot (Figure 1A) and total (Figure 1B) dry matter, highlighting fungi $A$. sydowii and Aspergillus sp. versicolor section, with values of 30.83 and $33.40 \mathrm{~g} / \mathrm{plant}$, respectively, for shoot dry matter, and 47.71 and $51.20 \mathrm{~g} / \mathrm{plant}$, respectively, for total dry matter, compared with control treatment, which was $23.40 \mathrm{~g} /$ plant for shoot dry matter and $30.04 \mathrm{~g} /$ plant for total dry matter.

Plant-fungus associations are mainly established by two groups of fungi, mycorrhizal and endophytic fungi (Bonfante and Genre, 2010). Endophytic fungi are those capable of living endosymbiotically with plants without causing disease symptoms (Behie and Bidochka, 2014). They can act as plant growth promoters, increase germination rate, improve seedling establishment, and increase plant resistance to biotic and abiotic stresses, producing antimicrobial compounds, phytohormones, 


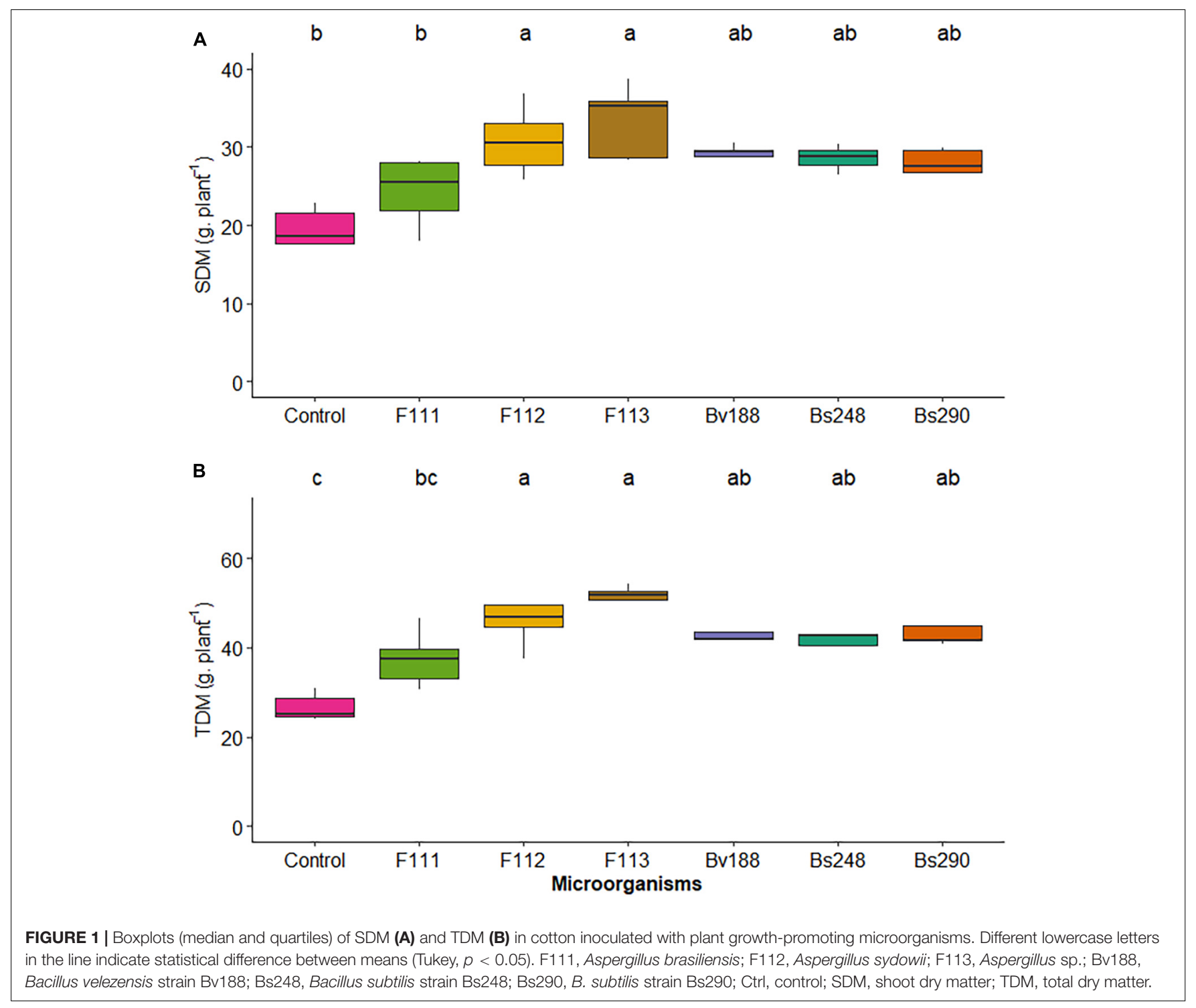

and other bioactive compounds. In addition, endophytic fungi are responsible for the acquisition of soil nutrients, including macronutrients such as phosphorus, nitrogen, potassium, and magnesium, and micronutrients such as zinc, iron, and copper (Behie and Bidochka, 2014; Rai et al., 2014; Khan et al., 2015).

Soil fungi are widely distributed and participate in ecological processes that influence plant growth and soil health. It is considered that the diversity of fungi that inhabit the soil and the rhizosphere can reach more than 200 species in a single soil (Vandenkoornhuyse et al., 2002).

Several Aspergillus species are commercially exploited due to their ability to produce and secrete many enzymes and metabolites, such as antibiotics and mycotoxins (VolkeSepulveda et al., 2016). The ability of fungi of the genus Aspergillus to produce secondary metabolites is very important because they play a vital role in survival and adaptation in soil; in addition, they are involved in the degradation of a wide range of natural organic substrates, particularly plant materials (Goldman and Osmani, 2008).

On the other hand, there was interaction between microorganism factor and inoculant concentration with variables nitrogen and phosphorus content in shoot (Figure 2) and root dry matter (Figure 3), soil phosphorus (Figure 4), soil nitrogen percentage (Figure 5), respiratory activity (Figure 6), colonyforming units in leaves (Figures 7, 8), and colony-forming units in roots and soil (Figure 9).

For fungus $A$. brasiliensis, the unfolding of interactions indicates that inoculation in cotton plants at a concentration of $1 \times 10^{6}$ conidia $\mathrm{ml}^{-1}$ favored the increase in shoot nitrogen content (22.75 g N/kg; Figure 2B); root and soil phosphorus contents were lower at concentrations of $1 \times 10^{4}$ and $1 \times 10^{8}$ conidia $\mathrm{ml}^{-1}$, with values of $2.09 \mathrm{~g} \mathrm{P} / \mathrm{kg}$ and $7.10 \mathrm{mg} \mathrm{P} / \mathrm{dm}^{3}$ soil, when compared with controls $(3.13 \mathrm{~g} \mathrm{P} / \mathrm{kg}$ and $26.91 \mathrm{mg} \mathrm{P} / \mathrm{dm}^{3}$ soil, respectively) (Figures 3I, 4B). Species of the genus Aspergillus, according to Souchie et al. (2006), 


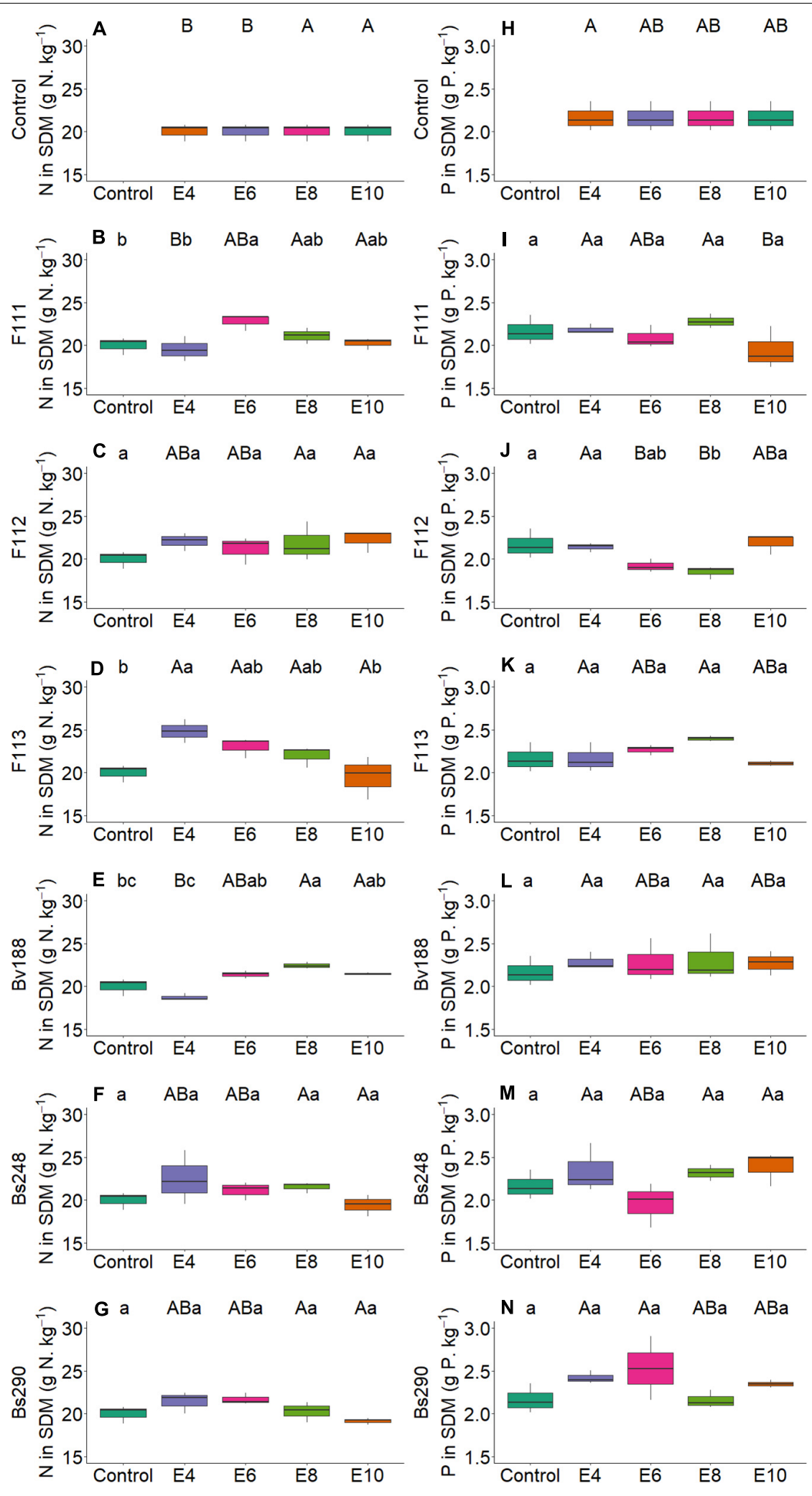

FIGURE 2 | Boxplots (median and quartiles) of nitrogen (A-G) and phosphorus (H-N) content in SDM in cotton inoculated with plant growth-promoting microorganisms. Different lowercase letters in a row and uppercase letters in a column indicate statistical difference between means (Tukey, $p<0.05$ ). F111, Aspergillus brasiliensis; F112, Aspergillus sydowii; F113, Aspergillus sp.; Bv188, Bacillus velezensis strain Bv188; Bs248, Bacillus subtilis strain Bs248; Bs290, B. subtilis strain Bs290; E4, $1 \times 10^{4}$; E6, 1 × 10 $0^{6}$; E8, $1 \times 10^{8}$; E10, $1 \times 10^{10}$ conidia or CFU mL ${ }^{-1}$; Ctrl, control; SDM, shoot dry matter. 


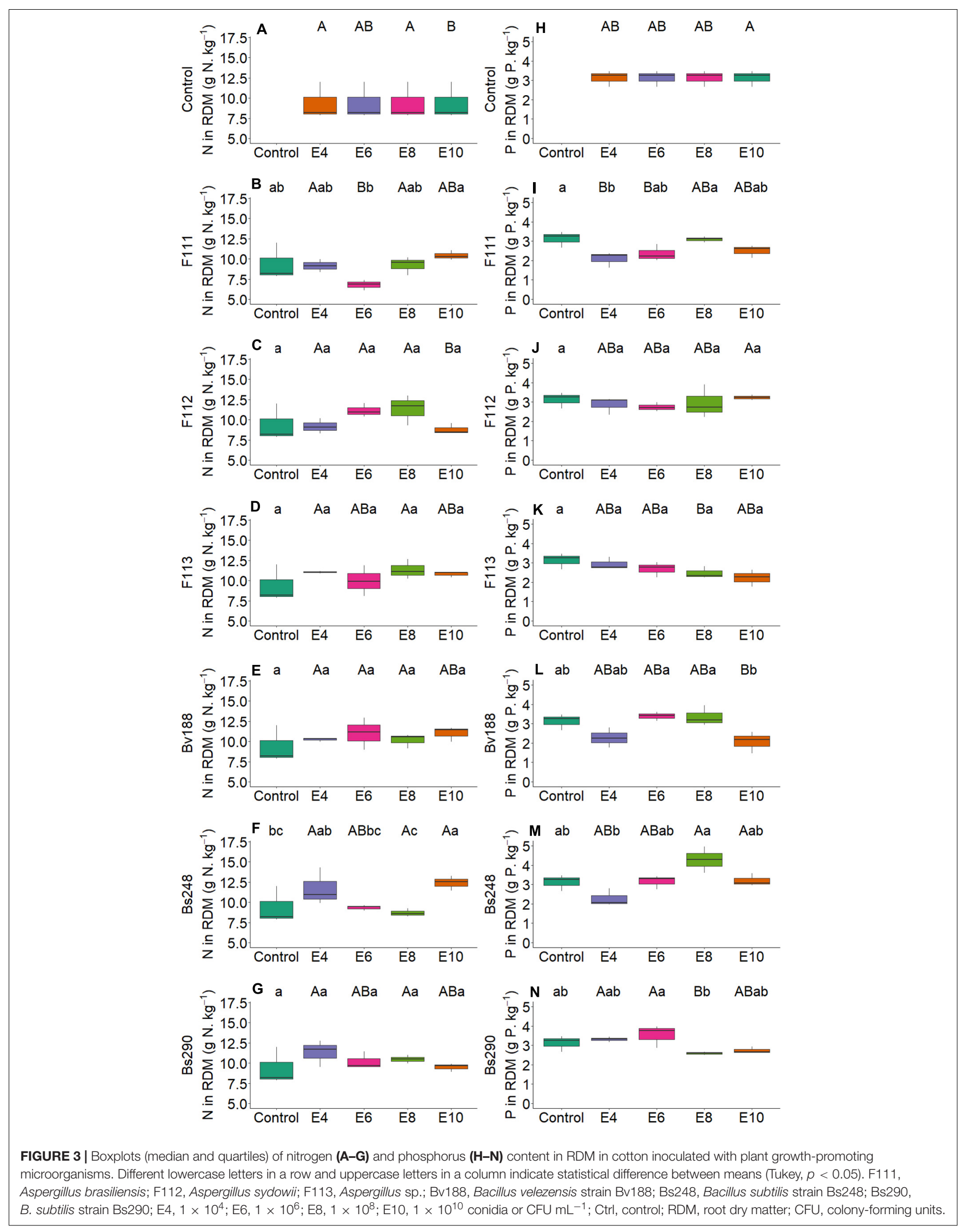




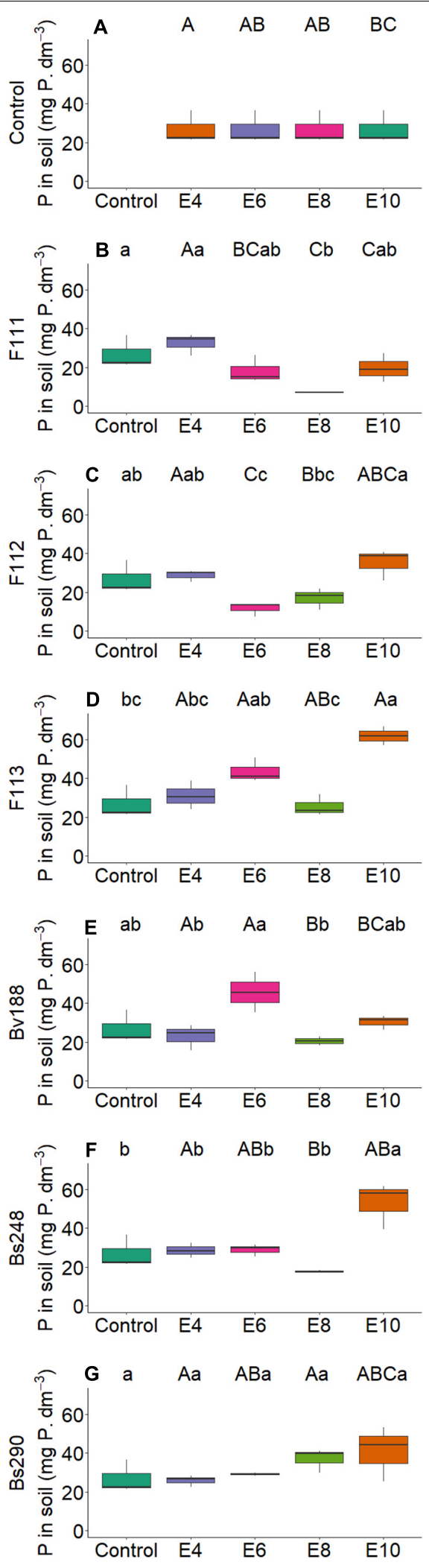

FIGURE 4 | Boxplots (median and quartiles) of phosphorus in soil sown with cotton and inoculated with plant growth-promoting microorganisms:

(Continued)
FIGURE 4 | (Continued)

Control (A); F111 (B); F112 (C); F113 (D); Bv188 (E); Bs248 (F); and Bs290

(G). Different lowercase letters in row and uppercase letters in column indicate statistical difference between the means (Tukey, $P<0.05$ ). Abbreviations:

F111, Aspergillus brasiliensis; F112, A. sydowii; F113, Aspergillus sp.; Bv188, B. velezensis strain Bv188; Bs248, B. subtilis strain Bs248; Bs290, B. subtilis strain Bs290; E4, $1 \times 10^{4}$; E6, $1 \times 10^{6}$, E8, $1 \times 10^{8}$; E10, $1 \times 10^{10}$ conidia or CFU/ml; Ctrl, Control; CFU, colony- forming units.

Pacheco and Damasio (2013), and de Oliveira Mendes et al. (2014), highlight the phosphorus solubilization capacity and its potential for use as solubilizers for different sources of phosphorus in the soil. Schneider et al. (2010) reported the ability to synthesize organic acids and produce large amounts of citric acid, which is one of the main factors responsible for the solubilization of phosphorus in these fungi. The soil nitrogen percentage was lower than that of control at all inoculant concentrations (Figure 5B). These results suggest that A. brasiliensis can serve as hosts for nitrogen-fixing bacteria (endosymbionts) (Paul et al., 2020). These interactions may allow the plant to have absorbed nitrogen fixed and/or contained in the soil. The nitrogen-fixing property is absent in eukaryotes, but they circumvented this deficiency by associating with nitrogenfixing bacteria (Kneip et al., 2007).

The soil respiratory activity reached the highest value (14.98 $\mathrm{mg} \mathrm{CO}_{2} / 100 \mathrm{~g}$ soil) at a concentration of $1 \times 10^{8}$ conidia $\mathrm{ml}^{-1}$ compared with control, $3.50 \mathrm{mg} \mathrm{CO}$ (Figure 6B); and the number of colony-forming units in leaves was higher for all inoculant concentrations compared with control (Figure 7B). For values of colony-forming units in roots, although presenting no interaction, there was a significant effect of the microorganism factor, where A. brasiliensis stood out, with $3.92 \mathrm{CFU} \mathrm{\textrm {mL } ^ { - 1 }}$ $(p<0.039$, Figure 9A); in addition, a positive correlation $(p<0.05)$ was observed between inoculant concentration and the number of colony-forming units in roots (Figure 10A). A. brasiliensis was isolated from the cotton plant, demonstrating that this fungus was probably able to colonize and enter the plant, showing its effects as an endophytic growth-promoting fungus on cotton. A. brasiliensis is described as a fast-growing and sporulating species, with characteristics closely related to Aspergillus niger (Varga et al., 2007); and A. sydowii is described as one of the fungi most commonly found in the soil (Raper and Fennell, 1965; Klich, 2002) and is used in industry for the production of enzymes such as $\beta$-glucosidase, $\alpha$-galactosidase, cellulase, and xylanase (Tian et al., 2016).

For A. sydowii, the unfolding of interactions indicates that the shoot phosphorus content presented lower value at a concentration of $1 \times 10^{8}$ conidia $\mathrm{ml}^{-1}(1.85 \mathrm{~g} \mathrm{P} / \mathrm{kg}$, Figure $2 \mathrm{~J})$ when compared with control $(2.17 \mathrm{~g} \mathrm{P} / \mathrm{kg})$; the soil phosphorus content was lower with $11.68 \mathrm{mg} \mathrm{P} / \mathrm{dm}^{3}$ at a concentration of $1 \times 10^{6}$ conidia $\mathrm{ml}^{-1}$, and control reached $26.91 \mathrm{mg}$ $\mathrm{P} / \mathrm{dm}^{3}$ (Figure 4C); the nitrogen percentage in soil inoculated with A. sydowii at all concentrations was lower than that of control (Figure 5C); the soil respiratory activity was higher (10.43 mg $\mathrm{CO}_{2} / 100$ soil) with inoculation at a concentration of $1 \times 10^{8}$ conidia $\mathrm{ml}^{-1}$ compared with control, which was 

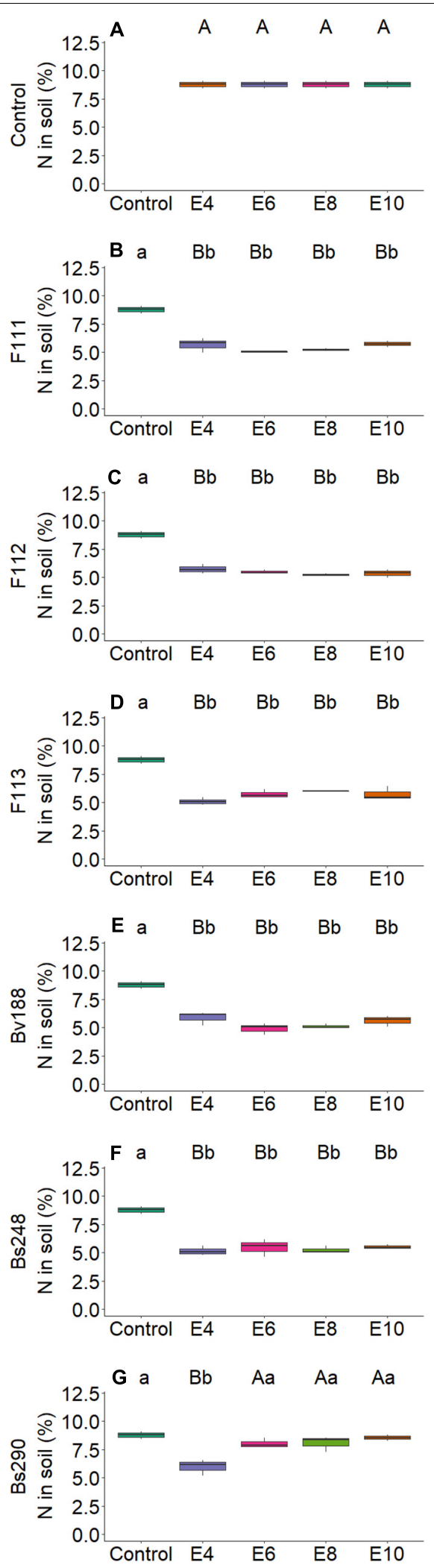

FIGURE 5 | Boxplots (median and quartiles) of percentage of nitrogen in soil sown with cotton and inoculated with plant growth-promoting

(Continued)
FIGURE 5 | (Continued)

microorganisms: Control (A); F111 (B); F112 (C); F113 (D); Bv188 (E); Bs248

(F); and Bs290 (G). Different lowercase letters in row and uppercase letters in column indicate statistical difference between means (Tukey, $P<0.05$ ). Abbreviations: F111, Aspergillus brasiliensis; F112, A. sydowii; F113, Aspergillus sp.; Bv188, B. velezensis strain Bv188; Bs248, B. subtilis strain Bs248; Bs290, B. subtilis strain Bs290; E4, 1 × 104 ; E6, $1 \times 10^{6}$; E8, $1 \times 10^{8}$; E10, $1 \times 10^{10}$ conidia or CFU/ml; Ctrl, Control; CFU, colonyforming units.

$3.5 \mathrm{mg} \mathrm{CO} / 100$ soil (Figure 6C) and for colony-forming units in leaves, highlighting inoculation of $A$. sydowii at a concentration of $1 \times 10^{10}$ conidia $\mathrm{ml}^{-1}$ with $43.00 \mathrm{CFU} \mathrm{mL} \mathrm{m}^{-1}$ compared with control, 1.33 CFU mL $\mathrm{CL}^{-1}$ (Figure 7C).

For Aspergillus sp. versicolor section, the interaction indicates that the highest nitrogen content in shoot dry matter was obtained at the lowest concentration of $1 \times 10^{4}$ conidia $\mathrm{ml}^{-1}$ (24.86 g N/kg; Figure 2D), when compared with control, $20.02 \mathrm{~g}$ $\mathrm{N} / \mathrm{kg}$; there was a positive correlation $(p<0.05$, Figure 10C) between inoculum concentration and soluble phosphorus in soil, and the largest amount $\left(62.00 \mathrm{mg} \mathrm{P} / \mathrm{dm}^{3}\right.$ soil) was obtained at a concentration of $1 \times 10^{10}$ conidia $\mathrm{ml}^{-1}$ (Figure 4D) and control only $26.91 \mathrm{mg} \mathrm{P} / \mathrm{dm}^{3}$ soil; and the soil nitrogen percentage was lower at all concentrations when compared with control (Figure 5D).

For colony-forming units in roots, there was a significant effect ( $p<0.039$, Figure 9A) of the microorganism factor, where Aspergillus sp. versicolor section stood out from

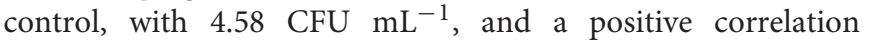
$(p<0.05)$ was observed between concentration and the number of colony-forming units in roots (Figure 10C). The greatest amount of $\mathrm{CFU} \mathrm{mL}^{-1}$ in roots and soil was reached when plants were inoculated at maximum concentration $\left(1 \times 10^{10}\right.$ conidia $\left.\mathrm{ml}^{-1}\right)$, regardless of fungus used (A. brasiliensis, A. sydowii, and Aspergillus sp. versicolor section) (Figures 9B,C).

For A. brasiliensis and A. sydowii, the increase in inoculum concentration had a positive effect on variable colony-forming units in leaves (Figures 7B,C); however, a concentration of $1 \times 10^{6}$ conidia $\mathrm{ml}^{-1}$ of $A$. brasiliensis proved to be appropriate to obtain higher shoot nitrogen contents (Figure $2 \mathbf{B}$ ), and a concentration of $1 \times 10^{8}$ conidia $\mathrm{ml}^{-1}$ of $A$. brasiliensis or A. sydowii was suitable for higher respiratory activity values (Figures 6B,C).

The highest inoculant concentrations promoted the highest numbers of $\mathrm{CFU} \mathrm{mL}^{-1}$ recovered from cotton roots and leaves. Endophytism promotes a more intimate interaction between a microorganism and a host, intensifying the benefits for both (Hardoim et al., 2008; Nadeem et al., 2014; Khan et al., 2015). Interestingly, treatments that presented a greater number of endophytic microorganisms did not necessarily promote greater plant development. Lobo et al. (2019) verified that the treatment that promoted a higher maize yield under field conditions, compared with control, also presented a lower number of recovered CFU $\mathrm{mL}^{-1}$. These results suggest that the growthpromoting effect probably depends more on the abilities of 


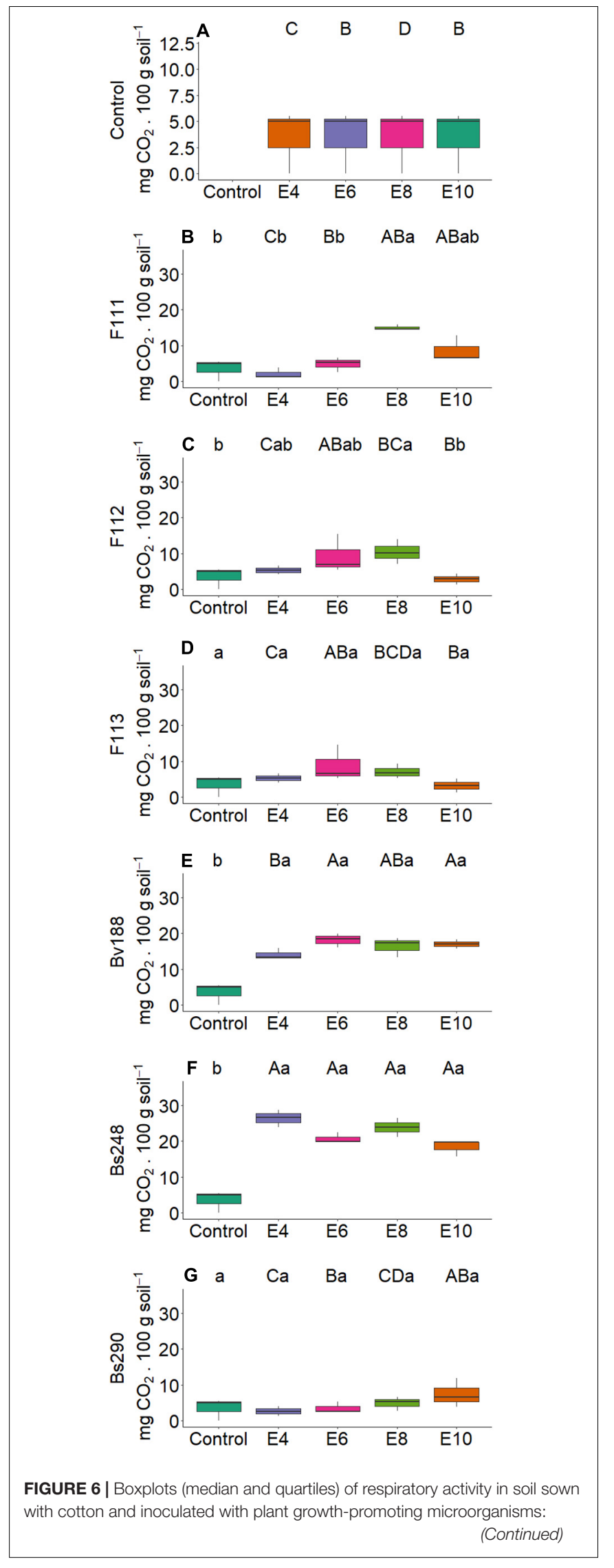

FIGURE 6 | (Continued)

Control (A); F111 (B); F112 (C); F113 (D); Bv188 (E); Bs248 (F); and Bs290

(G). Different lowercase letters in row and uppercase letters in column indicate statistical difference between means (Tukey, $P<0.05$ ). Abbreviations: F111, Aspergillus brasiliensis; F112, A. sydowii; F113, Aspergillus sp.; Bv188, B. velezensis strain Bv188; Bs248, B. subtilis strain Bs248; Bs290, B. subtilis strain Bs290; E4, $1 \times 10^{4}$; E6, $1 \times 10^{6}$; E8, $1 \times 10^{8}$; E10, $1 \times 10^{10}$ conidia or CFU/ml; Ctrl, Control; CFU, colony-forming units.

microorganisms and the interaction between microorganism and plant than on higher $\mathrm{CFU} \mathrm{mL} \mathrm{m}^{-1}$ values.

According to results of the present study, the hypothesis that the highest $A$. brasiliensis and A. sydowii concentrations positively affect microorganism colonization can be confirmed. However, this greater colonization did not reflect in greater plant development. These results also show that $A$. brasiliensis and A. sydowii are fungi with endophytic capacity in cotton plants. This characteristic in both fungi is an advantage because the endophytic colonization of plant tissues allows the fungus to establish itself inside the organs for some time without causing apparent damage to the host (Petrini, 1991), in addition to protecting plants against eventual colonization and pathogen infection or pest infestation (Bulgarelli et al., 2013). Studies carried out in China have shown that $A$. niger P 85 has the ability to solubilize phosphorus, produce indole acetic acid in maize plants, and increase available phosphorus in the soil (Yin et al., 2015); and in Brazil, similar studies have demonstrated the ability of A. sydowii and A. brasiliensis as phosphorus solubilizers in maize plants (Baron et al., 2018). A. brasiliensis and A. sydowii have great potential for use in other agricultural crops of great economic importance.

For Aspergillus sp. versicolor section, increasing inoculum concentration had a positive effect on soil phosphorus concentration and number of colony-forming units in roots (Figures 10B,C); however, a concentration of $1 \times 10^{4}$ conidia $\mathrm{ml}^{-1}$ was suitable for cotton plants to show the highest shoot nitrogen content (Figure 2D).

Aspergillus sp. versicolor section are accepted as distinct species based on molecular and phenotypic differences, are isolated from soil, and adapt to form part of the rhizospheric plant community (Zeljko et al., 2012). Aspergillus sp. versicolor section are fungi that are part of the microbial community of the rhizosphere of tea plants (Rahi et al., 2009). Similarly, in the present study, Aspergillus sp. versicolor section showed soil phosphorus solubilization capacity and root colonization. These characteristics are interesting in agriculture because inoculation with higher Aspergillus sp. versicolor section concentrations could decrease the need for use of mineral fertilizers in the field (Qiao et al., 2019; Caruso et al., 2020) as a consequence of the more efficient use of these fertilizers by plants. Some studies have shown that the association of this fungus with roots promotes abiotic stress tolerance and protection against pathogens (Singh et al., 2012; Begum et al., 2019; Rana et al., 2019).

For B. velezensis, the unfolding of interactions indicates that the nitrogen content in shoot dry matter of cotton plants was higher with $22.46 \mathrm{~g} \mathrm{~N} / \mathrm{kg}$ at a concentration 

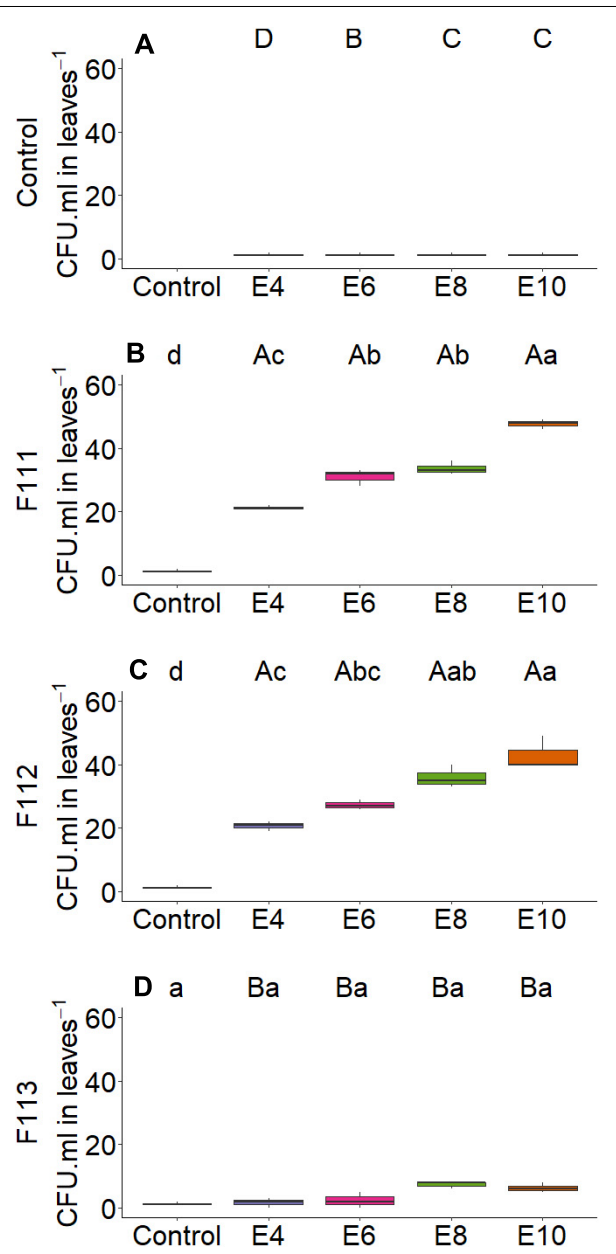

FIGURE 7 | Boxplots (median and quartiles) of CFU in cotton leaves inoculated with (A) Aspergillus brasiliensis (B), Aspergillus sydowii (C), and Aspergillus sp. (D) in four concentrations. Different lowercase letters in a row and uppercase letters in a column indicate statistical difference between means (Tukey, $p$ < 0.05). F111, Aspergillus brasiliensis; F112, A. sydowii; F113, Aspergillus sp.; E4, $1 \times 10^{4}$; E6, $1 \times 10^{6}$; E8, $1 \times 10^{8}$; E10, $1 \times 10^{10}$ conidia or CFU mL ${ }^{-1}$; Ctrl, control; and CFU, colony-forming units.

of $1 \times 10^{8} \mathrm{CFU} \mathrm{mL} \mathrm{mL}^{-1}$ compared with control, $20.02 \mathrm{~g} \mathrm{~N} / \mathrm{kg}$ (Figure 2E); the phosphorus content in the root dry matter and in the soil at all concentrations did not differ from that of control (Figures 3L, 4E); the soil nitrogen percentage was lower at all concentrations compared with that of control (Figure 5E); the respiratory activity was higher at all concentrations when compared with that of control (Figure 6E); the amount of colony-forming units in leaves, roots, and soil was higher at a concentration of $1 \times 10^{10} \mathrm{CFU} \mathrm{mL} \mathrm{m}^{-1}$ (34.00, 93.67, and

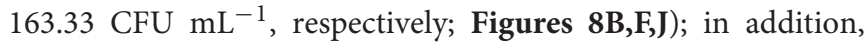
there was a positive correlation between concentration and colony-forming units in leaves ( $p<0.05$, Figure 10D).

For inoculation of B. subtilis Bs 248 , interaction indicates that the concentration of $1 \times 10^{10} \mathrm{CFU} \mathrm{mL} \mathrm{mL}^{-1}$ in cotton plants promoted the highest nitrogen content in the root dry matter $(12.41 \mathrm{~g} \mathrm{~N} / \mathrm{kg})$ when compared with control $(9.35 \mathrm{~g} \mathrm{~N} / \mathrm{kg})$
(Figure 3F); the phosphorus content in the root dry matter was not affected by concentration (Figure 3M); soil phosphorus at a concentration of $1 \times 10^{10} \mathrm{CFU} \mathrm{mL}^{-1}$ was approximately double $\left(53.15 \mathrm{mg} \mathrm{P} / \mathrm{dm}^{3}\right)$ that found at concentrations of $1 \times 10^{4}$, $1 \times 10^{6}$, and $1 \times 10^{8} \mathrm{CFU} \mathrm{mL}^{-1}$ and control (Figure $4 \mathrm{~F}$ ); in addition, there was a positive correlation between variable soil phosphorus and concentration $(p<0.05$, Figure 10E); soil nitrogen percentage was lower, and the respiratory activity was higher when B. subtilis Bs 248 was inoculated at any concentration (Figures 5F, 6F). The number of colony-forming units in leaves was higher when inoculum was applied at concentrations

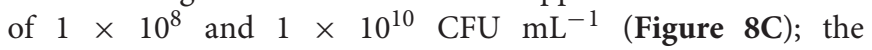
number of colony-forming units in roots was greater when inoculum was applied at a concentration of $1 \times 10^{6} \mathrm{CFU} \mathrm{mL}^{-1}$ (Figure 8G), and the number of colony-forming units in soil was greater at concentrations of $1 \times 10^{6}$ and $1 \times 10^{10} \mathrm{CFU}$ $\mathrm{mL}^{-1}$ (Figure 8K).

For B. subtilis Bs 290 , interaction indicates that the inoculation of cotton plants at a concentration of $1 \times 10^{4} \mathrm{CFU} \mathrm{mL}-1$ had the lowest nitrogen percentage, 5.97\%, when compared with control, which reached $8.77 \%$ (Figure 5G), and a smaller amount of colony-forming units in leaves with $5.00 \mathrm{CFU} \mathrm{mL}^{-1}$, when compared with control of $18.00 \mathrm{CFU} \mathrm{mL}^{-1}$ (Figure 8D); the number of colony-forming units in roots was higher, with

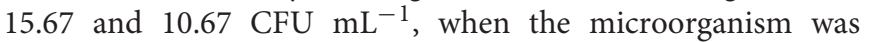
inoculated at concentrations of $1 \times 10^{6}$ and $1 \times 10^{8} \mathrm{CFU} \mathrm{mL}^{-1}$, respectively (Figure $\mathbf{8 H}$ ); and the number of colony-forming units in soil was higher, with 192.67 and $194.33 \mathrm{CFU} \mathrm{mL}^{-1}$, when inoculated at concentrations of $1 \times 10^{8}$ and $1 \times 10^{10} \mathrm{CFU} \mathrm{mL}{ }^{-1}$, respectively (Figure $\mathbf{8 L}$ ). Additionally, a positive correlation was observed between concentration and respiratory activity $(p<0.05$, Figure 10F)

Most Bacillus species are considered plant growth-promoting rhizobacteria and have the ability to colonize roots, improve nutrient availability, reduce abiotic stress, and produce a wide range of biologically active secondary metabolites that can inhibit the growth of pathogens (Ongena and Jacques, 2008; Lugtenberg and Kamilova, 2009; Bhattacharyya and Jha, 2012; Sivasakthi et al., 2014). The increase in inoculum concentration had a positive effect on variable colony-forming units in leaves for B. velezensis, soil phosphorus for B. subtilis Bs 248 , and a respiratory activity for B. subtilis Bs290.

Bacillus velezensis was previously grouped with B. subtilis and Bacillus amyloliquefaciens, and in recent years, several isolates of this bacterium have received attention due to their potential in disease control (Fan et al., 2017; Adeniji et al., 2019). Previous studies have determined that $B$. velezensis has the ability to produce indole acetic acid in pepper plants applied at a concentration of $1 \times 10^{8} \mathrm{CFU} \mathrm{mL}^{-1}$ (Zhang et al., 2019); in addition, it has been shown that metabolites produced have an antagonistic activity against bacterial and fungal pathogens under laboratory and greenhouse conditions in tomato crops (Cao et al., 2018). In the present study, B. velezensis showed the ability to colonize cotton leaves as the inoculum concentration increases. These results demonstrate that $B$. velezensis is an endophytic bacterium with capacity to promote growth through nitrogen content in shoot dry matter; in addition, results of 


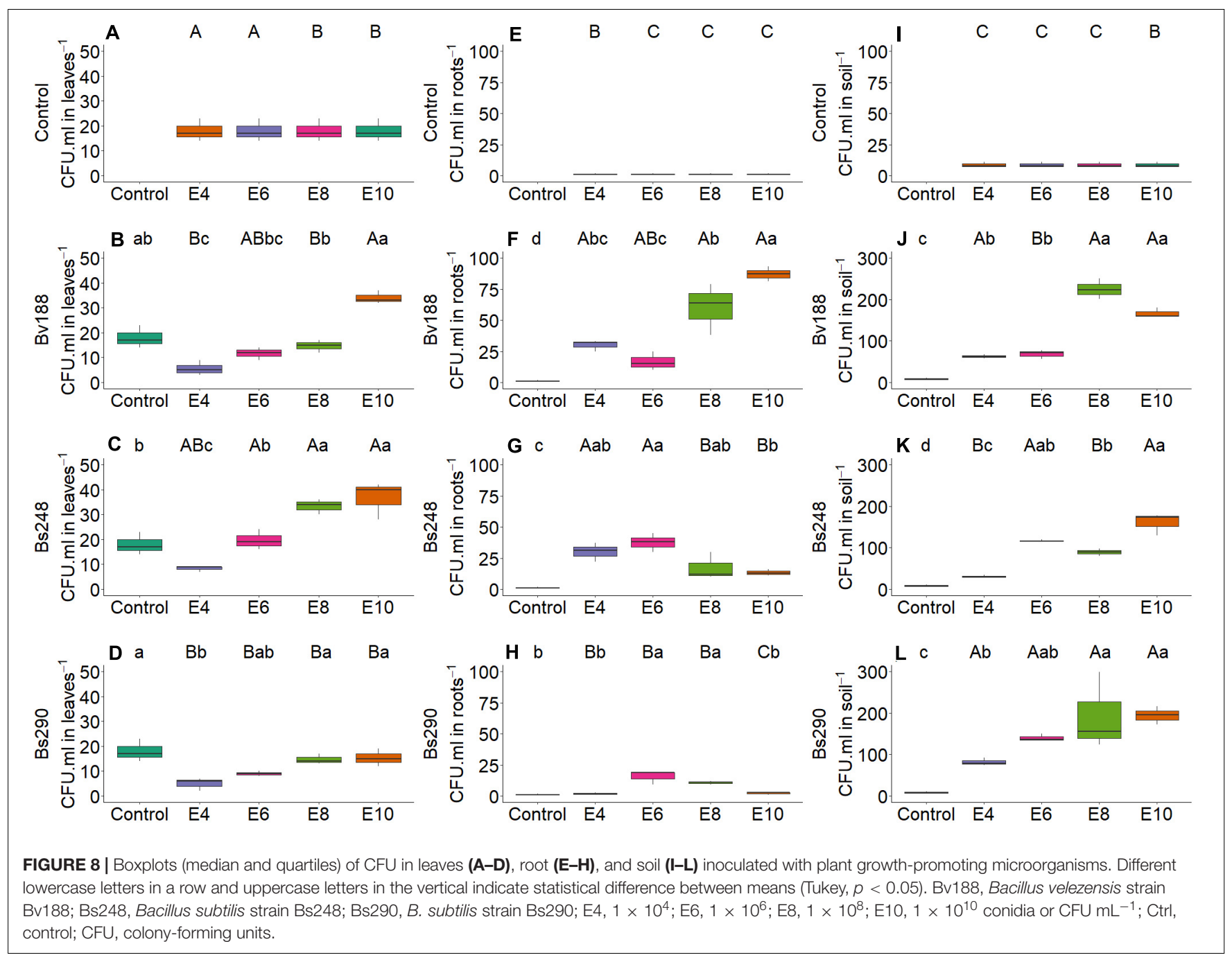

colony-forming units in leaves suggest that $B$. velezensis has potential to inhibit the growth of pathogens in cotton plants.

On the other hand, studies have demonstrated the ability of $B$. subtilis to solubilize phosphate, produce indole acetic acid and siderophores, and increase dry weight in maize and sorghum (Aquino et al., 2019), okra, spinach, and tomato plants, in addition to presenting antagonistic action against Rhizoctonia solani (Adesemoye et al., 2009). Regarding colonization, studies carried out with cucumber and tomato plants inoculated with $B$. subtilis at concentrations of $10^{5}$ and $10^{6} \mathrm{CFU} \mathrm{mL} \mathrm{m}^{-1}$ of root were enough for the microorganism to be able to colonize and survive in the rhizosphere. Thus, in addition to protecting plants by suppressing Fusarium oxysporum from cucumber, B. subtilis had an antagonistic effect against Pseudomonas syringae after root colonization in tomato plants (Cao et al., 2011; Chen et al., 2013). In the present study, B. subtilis strains have shown a correlation between soil phosphorus content and respiratory activity. These results suggest that to improve phosphorus solubilization and respiration in the soil, it is necessary to increase inoculum concentration.
On the other hand, studies have shown that the long-term continuous use of inoculants influences the quantity and quality of microorganisms present in the soil rhizosphere, but this depends on conditions such as organic matter, availability of nutrients (such as phosphorus), and type of soil (Gnankambary et al., 2008; Angelina et al., 2020). Furthermore, it is important to consider that the composition of the soil community is largely influenced by environmental variability and the microbial community present in the soil (Xun et al., 2015).

As one of the most important and essential macronutrients in addition to nitrogen, phosphorus is important for plant development, but it is the nutrient element least mobile in plant and soil. Globally, $\mathrm{P}$ is extracted from geological sediments and added to agricultural soils in order to meet critical plant requirements for agronomic productivity. Phosphorus is present in soil in the organic and inorganic forms. The various inorganic forms of the element in the soil are salts with calcium, iron, and aluminum, while the organic forms come from decomposing vegetation and microbial residues. There is great diversity of plant microbiomes (epiphytic, endophytic, and rhizospheric) and soil microbiomes that have the ability to solubilize insoluble $\mathrm{P}$ and 

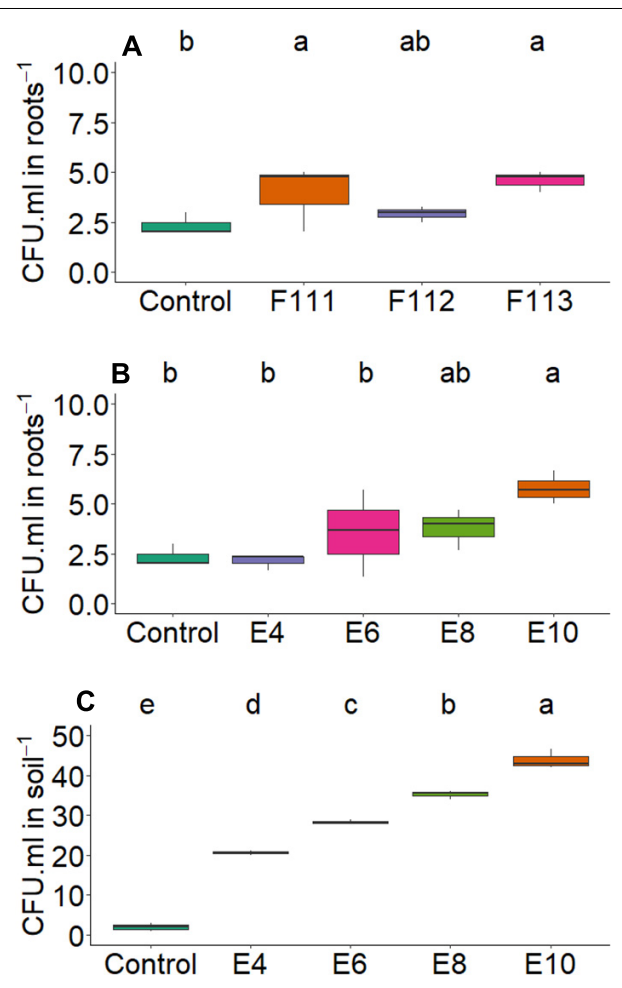

FIGURE 9 | Boxplots (median and quartiles) of CFU in root (A,B) and soil (C) inoculated with Aspergillus brasiliensis, Aspergillus sydowii, and Aspergillus $\mathrm{sp}$. Different lowercase letters in a row indicate statistical difference between means (Tukey, $p<0.05$ ). F111, Aspergillus brasiliensis; F112, A. sydowii; F113, Aspergillus sp.; E4, $1 \times 10^{4}$; E6, $1 \times 10^{6}$; E8, $1 \times 10^{8}$; E10, $1 \times 10^{10}$ conidia or $\mathrm{CFU} \mathrm{mL} \mathrm{mL}^{-1}$; Ctrl, control; CFU, colony-forming units.

make it available for plants. The main solubilization mechanism of inorganic $\mathrm{P}$ is by the production of organic acids, which lower soil $\mathrm{pH}$, or by the production of acids and alkaline phosphatases, which cause the mineralization of organic P. P-solubilizing and P-mobilizing microorganisms belong to all three domains: archaea, bacteria, and eukarya. Strains belonging to genera Arthrobacter, Bacillus, Burkholderia, Natrinema, Pseudomonas, Rhizobium, Serratia, and Aspergillus have been reported as efficient and potential $\mathrm{P}$ solubilizers. The use of $\mathrm{P}$ solubilizers, alone or in combination with another plant growth-promoting microbe as an ecological microbial consortium, could increase $\mathrm{P}$ uptake by plants, increasing their yields for agricultural and environmental sustainability (Kour et al., 2021). However, results have shown that for some treatments, phosphorus concentrations in soil and roots decreased. Factors such as mineral concentration, temperature, and availability of carbon and nitrogen $(\mathrm{N})$ sources can affect the phosphorus solubilization potential of these microorganisms, and these results suggest that there was greater solubilization and absorption of phosphorus from the soil by plants and greater translocation to shoots.

For the field phase, A. sydowii was selected for presenting abilities to promote a positive effect on variables shoot and total dry matter, soil respiratory activity, and colony-forming units in leaves and roots; Aspergillus sp. versicolor section were selected for presenting the ability to promote positive effects on variables shoot and total dry matter, nitrogen content in shoot dry matter, colony-forming units in roots and soil phosphorus; $B$. velezensis (Bv188) was selected for presenting the ability and promoting positive effects on variables nitrogen content in shoot dry matter, respiratory activity, colony-forming units in leaves, roots, and soil; and B. subtilis 248 was selected for presenting the ability to promote positive effects on variables root nitrogen content, soil phosphorus, respiratory activity in soil, and colony-forming units in leaves, roots, and soil.

\section{Experiment 2: Determination of the Effect of Inoculation of Microorganisms on Cotton Plants Under Field Conditions}

Regarding field yield, there was no interaction of concentration factor and microorganism factor on variables fiber yield (Figures 11A-E) and seed yield, except for Aspergillus sp. versicolor section (F113), which presented the lowest yield for

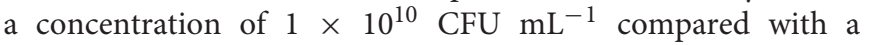
concentration of $1 \times 10^{4} \mathrm{CFU} \mathrm{mL} \mathrm{m}^{-1}$ (Figure 11H). Fiber yield in cotton plants inoculated with B. velezensis, B. subtilis 248, A. sydowii, and Aspergillus sp. versicolor section were superior to control, which had $326.94 \mathrm{~kg} / \mathrm{ha}$ (Figures 11A-F). Inoculation of $A$. sydowii at a concentration of $1 \times 10^{10}$ conidia $\mathrm{ml}^{-1}$ and Aspergillus sp. versicolor section at a concentration of $1 \times 10^{4}$ conidia $\mathrm{ml}^{-1}$ had the highest seed yield, with $1,131.14$ and $1,364.96 \mathrm{~kg} / \mathrm{ha}$, respectively (Figures $\mathbf{1 1 G}, \mathbf{H}$ ). Inoculation with $B$. velezensis at a concentration of $1 \times 10^{4}$ and $10^{10} \mathrm{CFU} \mathrm{mL}^{-1}$ showed no differences when compared with that with control (Figure 11I). Inoculation with B. subtilis Bs248 showed no differences between concentrations of $1 \times 10^{4}$ and

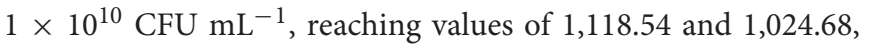
respectively (Figure 11J).

For A. sydowii and B. subtilis Bs248, the hypothesis that fiber and seed yield at concentrations of $1 \times 10^{4}$ or $1 \times 10^{10} \mathrm{CFU}$ $\mathrm{mL}^{-1}$ are similar is confirmed. Thus, the results of the present study demonstrate that there is no effect of concentration on cotton seed and fiber yield when inoculated with A. sydowii and B. subtilis Bs 248 and that there is no effect of concentration on cotton seed yield when inoculated with Aspergillus sp. versicolor section.

Yield studies performed with A. sydowii and Aspergillus sp. versicolor section in cotton are scarce in scientific literature; for example, studies carried out on chickpea plants have shown the ability of fungi Aspergillus awamori and Penicillium citrinum inoculated at a concentration of $1 \times 10^{6}$ spores $/ \mathrm{ml}$ to increase seed weight by approximately twice (Mittal et al., 2008). In addition, A. niger, Aspergillus fumigatus, and Penicillium pinophilum inoculated on wheat and fava beans at a concentration of $2 \times 10^{9}$ spores $/ \mathrm{ml}^{-1}$ increased yield by 28.9-32.8\% and 14.7-29.4\%, respectively (Abdul Wahid and Mehana, 2000). Likewise, phosphorus uptake by both cultures increased due to inoculation with tested fungi. Other studies include arbuscular mycorrhizal fungi in maize plants using concentrations of $1 \times 10^{3}$ spores $/ \mathrm{ml}$ where, in addition to 
A
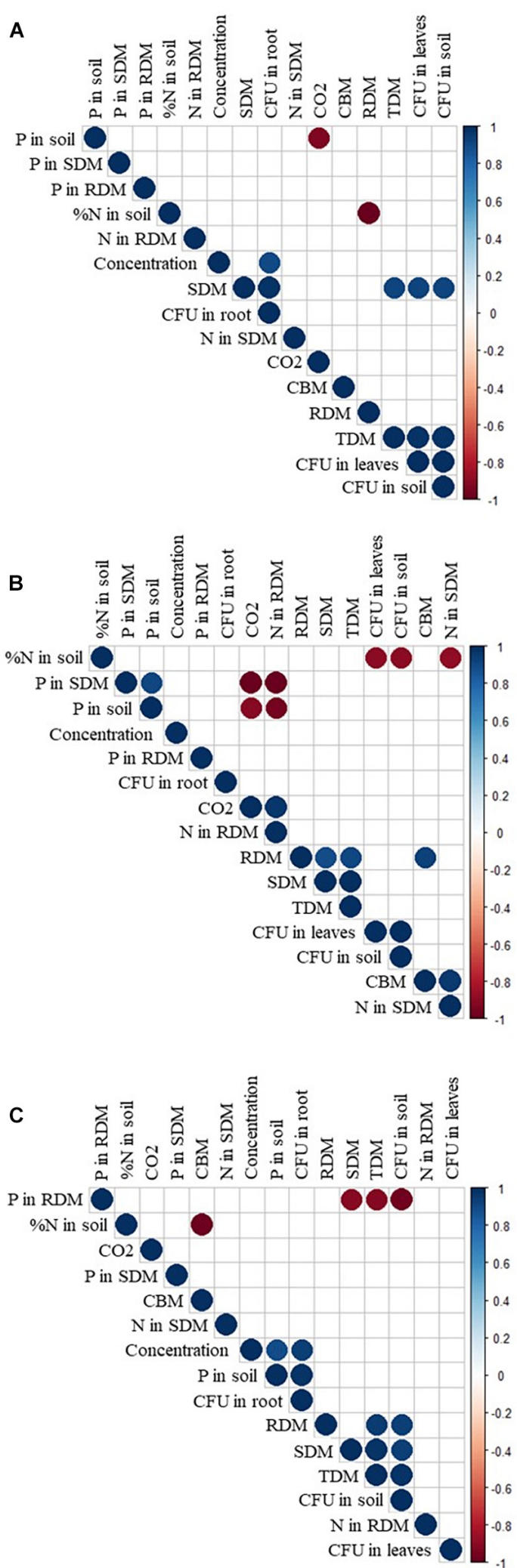
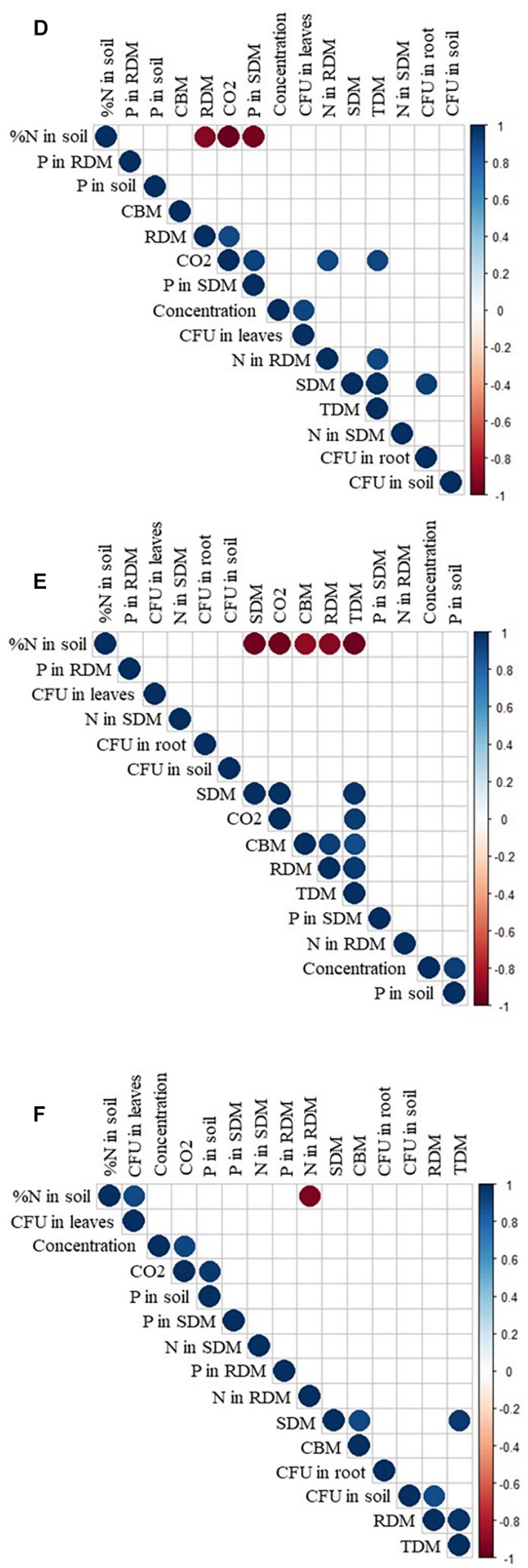

FIGURE $\mathbf{1 0}$ | Correlation of growth promotion variables and concentration of Aspergillus brasiliensis (A), Aspergillus sydowii (B), Aspergillus sp. (C), Bacillus velezensis (D), and Bacillus subtilis strain Bs248 (E) and Bs290 (F). P, phosphorus; N, nitrogen; SDM, shoot dry matter; RDM, root dry matter; TDM, total dry matter; $\mathrm{CO}_{2}$, respiratory activity; $\mathrm{CBM}$, biomass carbon; and $\mathrm{CFU}$, colony-forming units. 

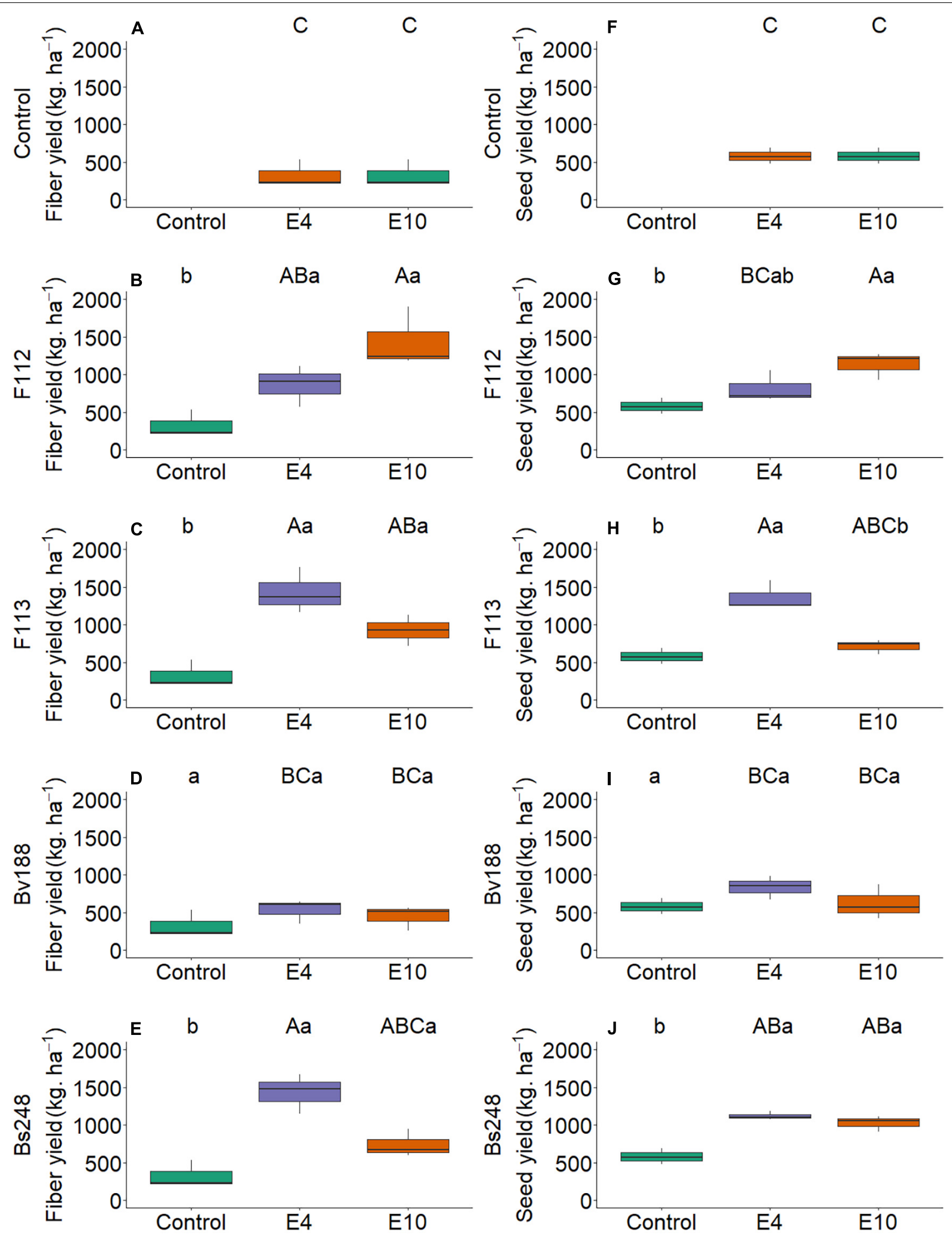

FIGURE 11 | Boxplots (median and quartiles) of fiber (A-E) and seed (F-J) cotton yield inoculated with plant growth-promoting microorganisms in two concentrations. Different lowercase letters in a row and uppercase letters in a column indicate statistical difference between means (Tukey, $p<0.05)$. F112, Aspergillus sydowii; F113, Aspergillus sp.; Bv188, Bacillus velezensis strain Bv188; Bs248, Bacillus subtilis strain Bs248; E4, $1 \times 10^{4}$; E10, $1 \times 10^{10}$ conidia or CFU $\mathrm{mL}^{-1}$; Ctrl, control; and CFU, colony-forming units. 
increasing yield by $80 \%$, these fungi are capable of inducing resistance against pathogenic A. niger strains (Molo et al., 2019).

For plant-growth promoting bacteria, Tripti et al. (2017) observed increase in the amount of fruits on tomato plants inoculated with Bacillus sp. strain A30 and Burkholderia sp. strain L2 at a concentration of $10^{10} \mathrm{CFU} \mathrm{mL}{ }^{-1}$. Furthermore, inoculation with $A$. brasiliensis $\mathrm{Ab}-\mathrm{V} 5$ and $B$. subtilis strain ССТВ04 at a concentration of $1 \times 10^{8} \mathrm{CFU} \mathrm{\textrm {mL } ^ { - 1 }}$ positively affected corn yield by 39.5 and $29.1 \%$, respectively (Pereira et al., 2020).

Microorganisms A. sydowii, Aspergillus sp. versicolor section, and B. subtilis Bs 248 used at concentrations of $1 \times 10^{4}$ and $1 \times 10^{10}$ conidia or $\mathrm{CFU} \mathrm{mL} \mathrm{mL}^{-1}$ in the field phase allow achieving similar results in cotton fiber and seed yield. These results show that lower inoculant concentrations could be used with no damage to plant growth efficiency promoted by the microbial isolate.

\section{CONCLUSION}

The parameters that were favored by the highest inoculant concentrations were soil respiratory activity, phosphorus in root dry matter, nitrogen in shoot dry matter, and number of colonyforming units in roots and leaves. Concentrations did not affect nitrogen in root dry matter, phosphorus in shoot dry matter, and microbial biomass carbon. However, other factors such

\section{REFERENCES}

Abdul Wahid, O. A., and Mehana, T. A. (2000). Impact of phosphatesolubilizing fungi on the yield and phosphorus-uptake by wheat and faba bean plants. Microbiol. Res. 155, 221-227. doi: 10.1016/S0944-5013(00)80 036-1

Adeniji, A. A., Loots, D. T., and Babalola, O. O. (2019). Bacillus velezensis: phylogeny, useful applications, and avenues for exploitation. Appl. Microbiol. Biotechnol. 103, 3669-3682. doi: 10.1007/s00253-019-09710-5

Adesemoye, A. O., Torbert, H. A., and Kloepper, J. W. (2009). Plant growthpromoting rhizobacteria allow reduced application rates of chemical fertilizers. Microb. Ecol. 58, 921-929. doi: 10.1007/s00248-009-9531-y

Ahmad, I., del Mar Jiménez-Gasco, M., Luthe, D. S., Shakeel, S. N., and Barbercheck, M. E. (2020). Endophytic Metarhizium robertsii promotes maize growth, suppresses insect growth, and alters plant defense gene expression. Biol. Control 144:104167. doi: 10.1016/j.biocontrol.2019.104167

Alori, E. T., and Babalola, O. O. (2018). Microbial inoculants for improving crop quality and human health in Africa. Front. Microbiol. 9:2213. doi: 10.3389/ fmicb.2018.02213

Angelina, E., Papatheodorou, E. M., Demirtzoglou, T., and Monokrousos, N. (2020). Effects of Bacillus subtilis and Pseudomonas fluorescens inoculation on attributes of the lettuce (Lactuca sativa L.) soil rhizosphere microbial community: the role of the management system. Agronomy 10:1428. doi: 10 . 3390/agronomy10091428

Aquino, J. P. A., Macedo, F. B. Jr., Antunes, J. E. L., Figueiredo, M. V. B., Alcantara Neto, F., and Araujo, A. S. F. (2019). Plant growth-promoting endophytic bacteria on maize and sorghum1. Pesqui. Agropecu. Trop. 49, 56241-56241. doi: 10.1590/1983-40632019v4956241

Baron, N. C., Costa, N. T. A., Mochi, D. A., and Rigobelo, E. C. (2018). First report of Aspergillus sydowii and Aspergillus brasiliensis as phosphorus solubilizers in maize. Ann. Microbiol. 68, 863-870. doi: 10.1007/s13213-018-1392-5

Baron, N. C., de Souza Pollo, A., and Rigobelo, E. C. (2020). Purpureocillium lilacinum and Metarhizium marquandii as plant growth-promoting fungi. PeerJ 8:e9005. doi: 10.7717/peerj.9005 as nitrogen and phosphorus contents in the soil, except for Aspergillus sp. versicolor section, were negatively affected with the highest inoculant concentrations. Interestingly, inoculant concentrations did not affect cotton fiber or seed yield.

The present study brings results that help in a better understanding of the effect of concentrations of fungi- and bacteria-based inoculants on the biometric parameters of plants, on microbial activities and soil fertility, on the nutritional status of plants, and on cotton crop productivity.

\section{DATA AVAILABILITY STATEMENT}

The raw data supporting the conclusions of this article will be made available by the authors, without undue reservation.

\section{AUTHOR CONTRIBUTIONS}

All authors listed have made a substantial, direct and intellectual contribution to the work, and approved it for publication.

\section{ACKNOWLEDGMENTS}

PE thank the Coordination for the Improvement of Higher Education Personnel (CAPES) for the granting of scholarship.

Begum, N., Qin, C., Ahanger, M. A., Raza, S., Khan, M. I., Ashraf, M., et al. (2019). Role of arbuscular mycorrhizal fungi in plant growth regulation: implications in abiotic stress tolerance. Front. Plant Sci. 10:1068. doi: 10.3389/fpls.2019.01068

Behie, S. W., and Bidochka, M. J. (2014). Nutrient transfer in plant-fungal symbioses. Trends Plant Sci. 19, 734-740. doi: 10.1016/j.tplants.2014.06.007

Bezerra Neto, E., and Barreto, L. P. (2011). Análises Químicas e Bioquímicas em Plantas. Recife: Editora Universitária da UFRPE.

Bhattacharyya, P. N., and Jha, D. K. (2012). Plant growth-promoting rhizobacteria (PGPR): emergence in agriculture. World J. Microbiol. Biotechnol. 28, 13271350. doi: 10.1007/s11274-011-0979-9

Bizos, G., Papatheodorou, E. M., Chatzistathis, T., Ntalli, N., Aschonitis, V. G., and Monokrousos, N. (2020). The role of microbial inoculants on plant protection, growth stimulation, and crop productivity of the olive tree (Olea europea L.). Plants 9:743. doi: 10.3390/plants9060743

Bonfante, P., and Genre, A. (2010). Mechanisms underlying beneficial plantfungus interactions in mycorrhizal symbiosis. Nat. Commun. 1:48. doi: 10.1038/ ncomms 1046

Bremner, J. M., and Mulvaney, C. S. (1983). "Nitrogen-Total," in Agronomy Monographs, 2ed Edn, ed. A. L. Page (Madison, WI: American Society of Agronomy, Soil Science Society of America), 595-624. doi: 10.2134/ agronmonogr9.2.2ed.c31

Brookes, P. C., Powlson, D. S., and Jenkinson, D. S. (1982). Measurement of microbial biomass phosphorus in soil. Soil Biol. Biochem. 14, 319-329. doi: 10.1016/0038-0717(82)90001-3

Bulgarelli, D., Schlaeppi, K., Spaepen, S., van Themaat, E. V. L., and Schulze-Lefert, P. (2013). Structure and functions of the bacterial microbiota of plants. Annu. Rev. Plant Biol. 64, 807-838. doi: 10.1146/annurev-arplant-050312-120106

Cao, Y., Pi, H., Chandrangsu, P., Li, Y., Wang, Y., Zhou, H., et al. (2018). Antagonism of two plant-growth promoting Bacillus velezensis isolates against Ralstonia solanacearum and Fusarium oxysporum. Sci. Rep. 8:4360. doi: 10. 1038/s41598-018-22782-Z

Cao, Y., Zhang, Z., Ling, N., Yuan, Y., Zheng, X., Shen, B., et al. (2011). Bacillus subtilis SQR 9 can control Fusarium wilt in cucumber by colonizing plant roots. Biol. Fertil. Soils 47, 495-506. doi: 10.1007/s00374-011-0556-2 
Caruso, G., Golubkina, N., Tallarita, A., Abdelhamid, M. T., and Sekara, A. (2020). Biodiversity, ecology, and secondary metabolites production of endophytic fungi associated with Amaryllidaceae crops. Agriculture 10:533. doi: 10.3390/ agriculture 10110533

Caruso, M., Colombo, A. L., Fedeli, L., Pavesi, A., Quaroni, S., Saracchi, M., et al. (2000). Isolation of endophytic fungi and actinomycetes taxane producers. Ann. Microbiol. 50, 3-13.

Carvalho, N. L., and Barcellos, A. L. (2012). Adoção do manejo integrado de pragas baseado na percepção e educação ambiental. Rev. Eletrôn. Gestão Educ. Tecnol. Ambient. 5, 749-766. doi: 10.5902/223611704204

Chen, Y., Yan, F., Chai, Y., Liu, H., Kolter, R., Losick, R., et al. (2013). Biocontrol of tomato wilt disease by Bacillus subtilis isolates from natural environments depends on conserved genes mediating biofilm formation. Environ. Microbiol. 15, 848-864. doi: 10.1111/j.1462-2920.2012.02860.x

de Araújo, W. L., de Souza Lima, A. O., de Azevedo, J. L., and Marcon, J. (2002). Manual: Isolamento de Microrganismos Endofíticos. Piracicaba: CALQ.

de Oliveira Mendes, G., Moreira de Freitas, A. L., Liparini Pereira, O., Ribeiro da Silva, I., Bojkov Vassilev, N., and Dutra Costa, M. (2014). Mechanisms of phosphate solubilization by fungal isolates when exposed to different $\mathrm{P}$ sources. Ann. Microbiol. 64, 239-249. doi: 10.1007/s13213-013-0656-3

Diaz, P. A. E., Baron, N. C., and Rigobelo, E. C. (2019). Bacillus spp. As plant growth-promoting bacteria in cotton under greenhouse conditions. Aust. J. Crop Sci. 13, 2003-2014. doi: 10.21475/ajcs.19.13.12.p2003

EMBRAPA (2006). Sistema Brasileiro de Classificação de Solos. Rio de Janeiro: Embrapa Solos.

Fan, B., Blom, J., Klenk, H. P., and Borriss, R. (2017). Bacillus amyloliquefaciens, Bacillus velezensis, and Bacillus siamensis form an "Operational Group B. amyloliquefaciens" within the B.subtilis species complex. Front. Microbiol. 8:22. doi: $10.3389 /$ fmicb.2017.00022

Glick, B. R., Patten, C. L., Holguin, G., and Penrose, D. M. (1999). Biochemical and Genetic Mechanisms used by Plant Growth-Promoting Bacteria. London: Imperial College Press.

Gnankambary, Z., Ilstedt, U., Nyberg, G., Hien, V., and Malmer, A. (2008). Nitrogen and phosphorus limitation of soil microbial respiration in two tropical agroforestry parklands in the south-Sudanese zone of Burkina Faso: the effects of tree canopy and fertilization. Soil Biol. Biochem. 40, 350-359. doi: 10.1016/j. soilbio.2007.08.015

Goldman, G. H., and Osmani, S. A. (2008). The Aspergilli Genomics, Medical aspects, Biotechnology, and Research Methods. Boca Raton, FL: CRC Press.

Haag, H. P., Sarruge, J. R., de Oliveira, G. D., Scoton, L. C., and Dechen, A. R. (1975). Nutrição mineral do cajueiro (Anacardium occidentale L.): III absorção de nutrientes - nota prévia. An. Esc. Super. Agric. Luiz Queiroz 32, 197-204. doi: 10.1590/S0071-12761975000100016

Hardoim, P. R., van Overbeek, L. S., and van Elsas, J. D. (2008). Properties of bacterial endophytes and their proposed role in plant growth. Trends Microbiol. 16, 463-471. doi: 10.1016/j.tim.2008.07.008

Islam, K. R., and Weil, R. R. (1998). Microwave irradiation of soil for routine measurement of microbial biomass carbon. Biol. Fertil. Soils 27, 408-416. doi: $10.1007 / \mathrm{s} 003740050451$

Jaber, L. R., and Enkerli, J. (2016). Effect of seed treatment duration on growth and colonization of Vicia faba by endophytic Beauveria bassiana and Metarhizium brunneum. Biol. Control 103, 187-195. doi: 10.1016/j.biocontrol.2016.09.008

Jenkinson, D. S., and Powlson, D. S. (1976). The effects of biocidal treatments on metabolism in soil-V. Soil Biol. Biochem. 8, 209-213. doi: 10.1016/00380717(76)90005-5

Khan, A. L., Hussain, J., Al-Harrasi, A., Al-Rawahi, A., and Lee, I. J. (2015). Endophytic fungi: resource for gibberellins and crop abiotic stress resistance. Crit. Rev. Biotechnol. 35, 62-74. doi: 10.3109/07388551.2013.800018

Klich, M. A. (2002). Biogeography of Aspergillus species in soil and litter. Mycologia 94, 21-27. doi: 10.1080/15572536.2003.11833245

Kloepper, J. W., Lifshitz, R., and Zablotowicz, R. M. (1989). Free-living bacterial inocula for enhancing crop productivity. Trends Biotechnol. 7, 39-44.

Kneip, C., Lockhart, P., Voss, C., and Maier, U. G. (2007). Nitrogen fixation in eukaryotes - new models for symbiosis. BMC Evol. Biol. 7:55. doi: 10.1186/ 1471-2148-7-55

Kour, D., Rana, K. L., Kaur, T., Yadav, N., Yadav, A. N., Kumar, M., et al. (2021). Biodiversity, current developments and potential biotechnological applications of phosphorus-solubilizing and -mobilizing microbes: a review. Pedosphere 31, 43-75. doi: 10.1016/S1002-0160(20)60057- 1

Lobo, L. L. B., dos Santos, R. M., and Rigobelo, E. C. (2019). Promotion of maize growth using endophytic bacteria under greenhouse and field conditions. Aust. J. Crop Sci. 13, 2067-2074. doi: 10.21475/ajcs.19.13.12.p2077

Lugtenberg, B., and Kamilova, F. (2009). Plant-growth-promoting rhizobacteria. Annu. Rev. Microbiol. 63, 541-556.

Malavolta, E., Vitti, G. C., and Oliveira, S. A. (1997). Avaliação do Estado Nutricional das Plantas: Princípios e Aplicações, 2 Edn. ed. Associação Brasileira para Pesquisa da Potassa e do Fosfato. Available online at: https://www.infraestruturameioambiente.sp.gov.br/institutodebotanica/1997/ 01/avaliacao-do-estado-nutricional-das-plantas-principios-e-aplicacoes/ (accessed August 12, 2020).

Malusá, E., and Vassilev, N. (2014). A contribution to set a legal framework for biofertilisers. Appl. Microbiol. Biotechnol. 98, 6599-6607. doi: 10.1007/s00253$014-5828-y$

Marulanda, A., Barea, J.-M., and Azcón, R. (2009). Stimulation of plant growth and drought tolerance by native microorganisms (AM Fungi and Bacteria) from dry environments: mechanisms related to bacterial effectiveness. J. Plant Growth Regul. 28, 115-124. doi: 10.1007/s00344-009-9079-6

Mendonça, E. D. S., and Matos, E. S. (2017). Matéria Orgânica do Solo: Métodos de Análises. ABEAS, 2nd Edn. Viçosa: Universidade Federal de Viçosa.

Michereff, S. J., and Barros, R. (2001). Proteção de Plantas na Agricultura Sustentável. Recife: UFRPE.

Milani, R., Santos, R. M. D., Bentes, L. L., Lazarovits, G., and Rigobelo, E. C. (2019). Bacillus subtilis isolates with different abilities to promote plant growth in maize, cotton and soybean crops isolation and characterization of bacterial strains. Asian J. Microbiol. Biotechnol. Environ. Sci. 21, 827-836.

Mittal, V., Singh, O., Nayyar, H., Kaur, J., and Tewari, R. (2008). Stimulatory effect of phosphate-solubilizing fungal strains (Aspergillus awamori and Penicillium citrinum) on the yield of chickpea (Cicer arietinum L. cv. GPF2). Soil Biol. Biochem. 40, 718-727. doi: 10.1016/j.soilbio.2007.10.008

Molo, M. S., Heiniger, R. W., Boerema, L., and Carbone, I. (2019). Trial summary on the comparison of various non-aflatoxigenic strains of Aspergillus flavus on mycotoxin levels and yield in maize. Agron. J. 111, 942-946. doi: 10.2134/ agronj2018.07.0473

Nadeem, S. M., Ahmad, M., Zahir, Z. A., Javaid, A., and Ashraf, M. (2014). The role of mycorrhizae and plant growth promoting rhizobacteria (PGPR) in improving crop productivity under stressful environments. Biotechnol. Adv. 32, 429-448. doi: 10.1016/j.biotechadv.2013. 12.005

Okon, Y., and Labandera-Gonzalez, C. A. (1994). Agronomic applications of Azospirillum: an evaluation of 20 years worldwide field inoculation. Soil Biol. Biochem. 26, 1591-1601. doi: 10.1016/0038-0717(94)90311-5

Ongena, M., and Jacques, P. (2008). Bacillus lipopeptides: versatile weapons for plant disease biocontrol. Trends Microbiol. 16, 115-125. doi: 10.1016/j.tim.2007. 12.009

Pacheco, S. M. V., and Damasio, F. (2013). Aplicação de microrganismos disponibilizadores de fosfato imobilizados em alginato de cálcio na agricultura. Rev. Eletrôn. Biol. 6:2.

Paul, K., Saha, C., Nag, M., Mandal, D., Naiya, H., Sen, D., et al. (2020). A tripartite interaction among the basidiomycete Rhodotorula mucilaginosa, N2fixing endobacteria, and rice improves plant nitrogen nutrition. Plant Cell 32, 486-507. doi: 10.1105/tpc. 19.00385

Pedraza, R. O., Teixeira, K. R., Fernández Scavino, A., García de Salamone, I., Baca, B. E., Azcón, R., et al. (2010). Microorganismos que mejoran el crecimiento de las plantas y la calidad de los suelos. Revisión. Corpoica. Cienc. Tecnol. Agropecu. 11:155.

Peel, M. C., Finlayson, B. L., and McMahon, T. A. (2007). Updated world map of the Köppen-Geiger climate classification. Hydrol. Earth Syst. Sci. 11, 1633-1644. doi: 10.5194/hess-11-1633-2007

Pereira, N. C. M., Galindo, F. S., Gazola, R. P. D., Dupas, E., Rosa, P. A. L., Mortinho, E. S., et al. (2020). Corn yield and phosphorus use efficiency response to phosphorus rates associated with plant growth promoting bacteria. Front. Environ. Sci. 8:40. doi: 10.3389/fenvs.2020.00040

Petrini, O. (1991). "Fungal endophytes of tree leaves," in Microbial Ecology of Leaves, eds J. H. Andrews, and S. S. Hirano (New York, NY: Springer), 179-197. doi: 10.1007/978-1-4612-3168-4_9 
Qiao, Q., Zhang, J., Ma, C., Wang, F., Chen, Y., Zhang, C., et al. (2019). Characterization and variation of the rhizosphere fungal community structure of cultivated tetraploid cotton. PLoS One 14:e0207903. doi: 10.1371/journal. pone. 0207903

R Core Team (2020). R: A Language and Environment for Statistical Computing. Vienna: R Foundation for Statistical Computing.

Rahi, P., Vyas, P., Sharma, S., Gulati, A., and Gulati, A. (2009). Plant growth promoting potential of the fungus Discosia sp. FIHB 571 from tea rhizosphere tested on chickpea, maize and pea. Ind. J. Microbiol. 49, 128-133. doi: 10.1007/ s12088-009-0026-9

Rai, M., Rathod, D., Agarkar, G., Dar, M., Brestic, M., Pastore, G. M., et al. (2014). Fungal growth promotor endophytes: a pragmatic approach towards sustainable food and agriculture. Symbiosis 62, 63-79. doi: 10.1007/s13199-014$0273-3$

Rana, K. L., Kour, D., and Yadav, A. N. (2019). Endophytic microbiomes: biodiversity, ecological significance and biotechnological applications. Res. J. Biotechnol. 14, 142-162.

Raper, K. B., and Fennell, D. I. (1965). The Genus Aspergillus. CIMMYT. Available online at: https://www.cabdirect.org/cabdirect/abstract/19662205082 (accessed August 12, 2020).

Samson, R. A., Visagie, C. M., Houbraken, J., Hong, S.-B., Hubka, V., Klaassen, C. H. W., et al. (2014). Phylogeny, identification and nomenclature of the genus Aspergillus. Stud. Mycol. 78, 141-173. doi: 10.1016/j.simyco.2014.07.004

Schneider, K. D., Van Straaten, P., De Orduña, R. M., Glasauer, S., Trevors, J., Fallow, D., et al. (2010). Comparing phosphorus mobilization strategies using Aspergillus niger for the mineral dissolution of three phosphate rocks. J. Appl. Microbiol. 108, 366-374. doi: 10.1111/j.1365-2672.2009.04489.x

Singh, V., Mawar, R., and Lodha, S. (2012). Combined effects of biocontrol agents and soil amendments on soil microbial populations, plant growth and incidence of charcoal rot of cowpea and wilt of cumin. Phytopathol. Mediterr. 51, 307-316.

Singh, Z., Kaur, J., Kaur, R., and Hundal, S. (2016). Toxic effects of organochlorine pesticides: a review. Am. J. Biosci. 4, 11-18. doi: 10.11648/j.ajbio.s.2016040301. 13

Sivasakthi, S., Usharani, G., and Saranraj, P. (2014). Biocontrol potentiality of plant growth promoting bacteria (PGPR) - Pseudomonas fluorescens and Bacillus subtilis: a review. Afr. J. Agric. Res. 9, 1265-1277. doi: 10.5897/AJAR2013. 7914

Souchie, E. L., Saggin-Júnior, O. J., Silva, E. M. R., Campello, E. F. C., Azcón, R., and Barea, J. M. (2006). Communities of P-solubilizing bacteria, fungi and arbuscular mycorrhizal fungi in grass pasture and secondary forest of Paraty, RJ - Brazil. An. Acad. Bras. Ciênc. 78, 183-193. doi: 10.1590/S000137652006000100016

Tahmatsidou, V., O'Sullivan, J., Cassells, A. C., Voyiatzis, D., and Paroussi, G. (2006). Comparison of AMF and PGPR inoculants for the suppression of Verticillium wilt of strawberry (Fragaria $\times$ ananassa cv. Selva). Appl. Soil Ecol. 32, 316-324. doi: 10.1016/j.apsoil.2005.07.008

Tian, J., Dong, Q., Yu, C., Zhao, R., Wang, J., and Chen, L. (2016). Biodegradation of the organophosphate trichlorfon and its major degradation products by a novel Aspergillus sydowii PA F-2. J. Agric. Food Chem. 64, 4280-4287. doi: 10.1021/acs.jafc.6b00909

Tripti, Kumar, A., Usmani, Z., Kumar, V., and Anshumali (2017). Biochar and flyash inoculated with plant growth promoting rhizobacteria act as potential biofertilizer for luxuriant growth and yield of tomato plant. J. Environ. Manage. 190, 20-27. doi: 10.1016/j.jenvman.2016.11.060

Vandenkoornhuyse, P., Baldauf, S. L., Leyval, C., Straczek, J., and Young, J. P. (2002). Extensive fungal diversity in plant roots. Science 295:2051. doi: 10.1126/ science.295.5562.2051
Varga, J., Kocsubé, S., Tóth, B., Frisvad, J. C., Perrone, G., Susca, A., et al. (2007). Aspergillus brasiliensis sp. Nov., a biseriate black Aspergillus species with worldwide distribution. Int. J. Syst. Evol. Microbiol. 57, 1925-1932. doi: 10.1099/ijs.0. 65021-0

Vieira, F. C. S., and Nahas, E. (2000). Quantification of total and sporulating bacteria in soils. Sci. Agric. 57, 539-545. doi: 10.1590/S010390162000000300026

Volke-Sepulveda, T., Salgado-Bautista, D., Bergmann, C., Wells, L., Gutierrez-Sanchez, G., and Favela-Torres, E. (2016). Secretomic insight into glucose metabolism of Aspergillus brasiliensis in solid-state fermentation. J. Proteome Res. 15, 3856-3871. doi: 10.1021/acs.jproteome. $6 \mathrm{~b} 00663$

Watanabe, F. S., and Olsen, S. R. (1965). Test of an ascorbic acid method for determining phosphorus in water and $\mathrm{NaHCO} 3$ extracts from soil. Soil Sci. Soc. Am. J. 29, 677-678. doi: 10.2136/sssaj1965.0361599500290006 $0025 \mathrm{x}$

Wilke, B. M. (2005). "Determination of chemical and physical soil properties," in Monitoring and Assessing Soil Bioremediation, eds R. Margesin, and F. Schinner (Berlin: Springer), 47-95. doi: 10.1007/3-540-28904-6_2

Wollum, A. G. (1982). "Cultural methods for soil microorganisms," in Methods of Soil Analysis. Part 2. Chemical and Microbiological Properties, eds A. L. Page, R. H. Miller, and D. R. Keeney (Madison, WI: American Society of Agronomy Monograph 9), 781-802.

Xun, F., Xie, B., Liu, S., and Guo, C. (2015). Effect of plant growth-promoting bacteria (PGPR) and arbuscular mycorrhizal fungi (AMF) inoculation on oats in saline-alkali soil contaminated by petroleum to enhance phytoremediation. Environ. Sci. Pollut. Res. 22, 598-608. doi: 10.1007/s11356-0143396-4

Yin, Z., Shi, F., Jiang, H., Roberts, D. P., Chen, S., and Fan, B. (2015). Phosphate solubilization and promotion of maize growth by Penicillium oxalicum $\mathrm{P} 4$ and Aspergillus niger P85 in a calcareous soil. Can. J. Microbiol. 61, 913-923. doi: 10.1139/cjm-2015-0358

Zeljko, J., Peterson, S. W., and Horn, B. W. (2012). Aspergillus section versicolores: nine new species and multilocus DNA sequence-based phylogeny. IMA Fungus 3, 59-79. doi: 10.5598/imafungus.2012.03.01.07

Zhang, L. N., Wang, D. C., Hu, Q., Dai, X. Q., Xie, Y. S., Li, Q., et al. (2019). Consortium of plant growth-promoting rhizobacteria strains suppresses sweet pepper disease by altering the rhizosphere microbiota. Front. Microbiol. 10:1668. doi: $10.3389 /$ fmicb. 2019.01668

Conflict of Interest: The authors declare that the research was conducted in the absence of any commercial or financial relationships that could be construed as a potential conflict of interest.

Publisher's Note: All claims expressed in this article are solely those of the authors and do not necessarily represent those of their affiliated organizations, or those of the publisher, the editors and the reviewers. Any product that may be evaluated in this article, or claim that may be made by its manufacturer, is not guaranteed or endorsed by the publisher.

Copyright (c) 2021 Escobar Diaz, dos Santos, Baron, Gil and Rigobelo. This is an open-access article distributed under the terms of the Creative Commons Attribution License (CC BY). The use, distribution or reproduction in other forums is permitted, provided the original author(s) and the copyright owner(s) are credited and that the original publication in this journal is cited, in accordance with accepted academic practice. No use, distribution or reproduction is permitted which does not comply with these terms. 